Historic, archived document

Do not assume content reflects current scientific knowledge, policies, or practices. 



\section{A35 \\ United States \\ Department of \\ Agriculture}

Forest

Service

North Central

Forest Experiment

Station

Resource Bulletin

NC-163

\section{The Forest Resources of the Hiawatha National Forest, 1993}

Thomas Schmidt and Mike Lanasa

进舟

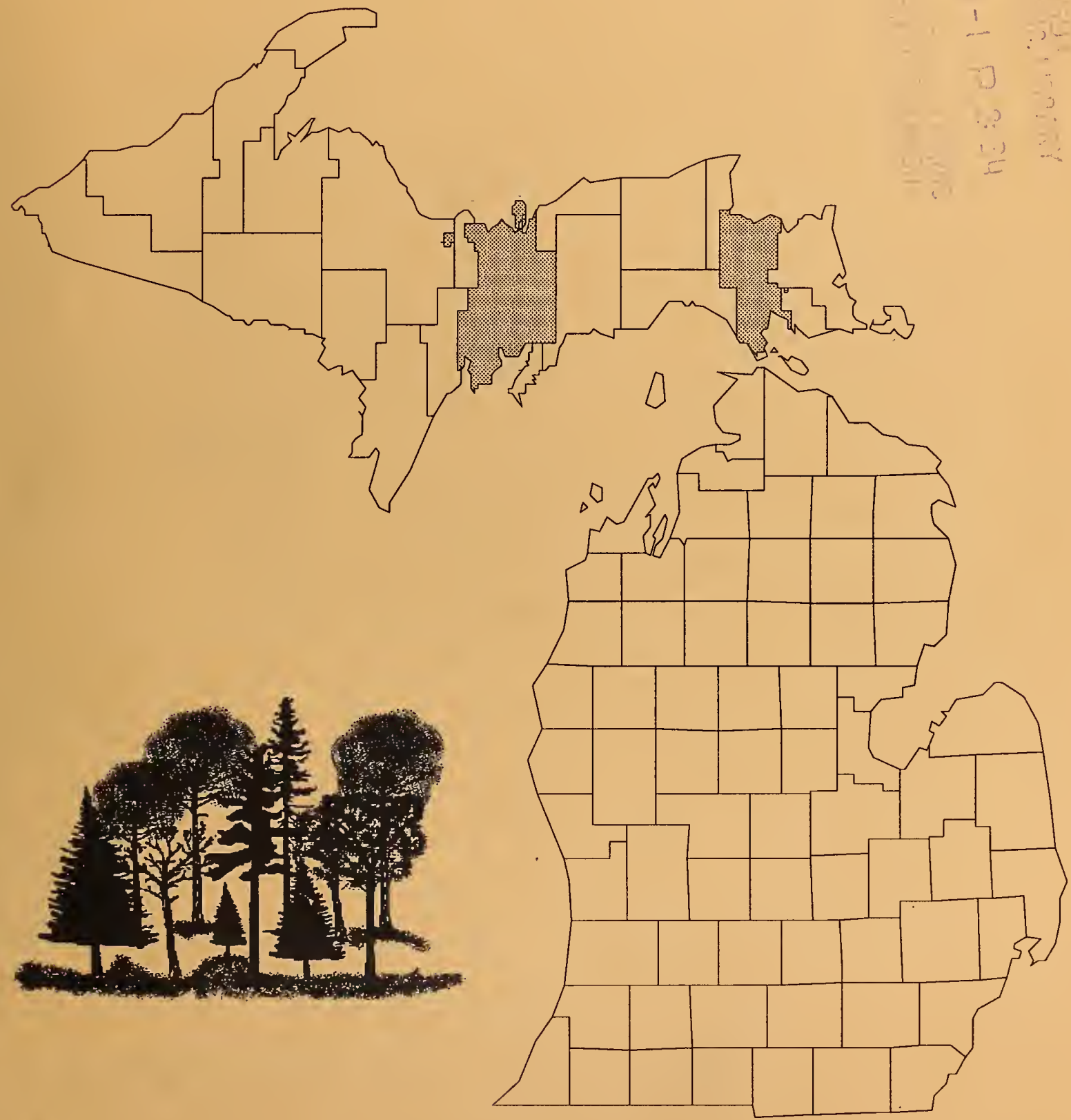


North Central Forest Experiment Station Forest Service-U.S. Department of Agriculture 1992 Folwell Avenue

St. Paul, Minnesota 55108

Manuscript approved for publication July 24, 1995 1995 
This report includes the most commonly used U.S. Department of Agriculture, Forest Service, Forest Inventory and Analysis (FIA) statistics. Additional forest resource data can be provided to interested users. Persons requesting additional information from the raw inventory data are expected to pay the retrieval costs. These costs range from less than $\$ 100$ for a relatively simple request to more than $\$ 2,000$ for a complex retrieval involving the services of a Forest Inventory and Analysis computer programmer. Requests will be filled so as to minimize the impact on the Forest Inventory and Analysis Work Unit.

Requests for information may be directed to:

Program Manager

Forest Inventory and Analysis

North Central Forest Experiment Station

1992 Folwell Avenue

St. Paul, Minnesota 55108

Phone: (612) 649-5139

or

Forest Supervisor

Hiawatha National Forest

2727 North Lincoln Road

Escanaba, Michigan 49829

Area served: Illinols, Indiana, Iowa, Kansas, Michigan, Minnesota, Missourl, Nebraska, North Dakota, South Dakota, Wisconsin. 


\section{Contents}

Extent of Forest Land on the Hiawatha National Forest

Composition of the Hiawatha's Forests.

Growth ............................................................................... 5

Mortality .......................................................................... 5

Removals ............................................................................ 6

Appendix .............................................................................. 6

Accuracy of the Survey ........................................................ 6

Survey Procedures ................................................................. 7

Major Steps in the Survey Design ........................................... 7

Tree and $\log$ Grades .................................................................. 10

Metric Equivalents of Units Used in This Report...............................15

Tree Species in the Hiawatha National Forest ....................................15

Definition of Terms ...................................................................... 15

Literature Cited ........................................................................ 19

Table Titles ....................................................................................20

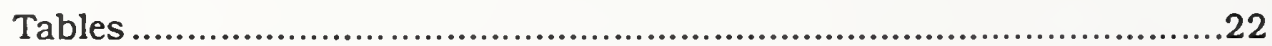




\title{
The Forest Resources of the Hiawatha National Forest, 1993
}

\author{
Thomas Schmidt and Mike Lanasa
}

The Hiawatha National Forest is located in the central and eastern parts of the Upper Peninsula of Michigan (fig. 1). What makes the Hiawatha special are the kinds of natural resources found here, their unique arrangements, and the associated north-country climate. The Hiawatha National Forest consists of 892,100 acres and boasts of more than 777 miles of rivers and streams, 104 miles of shoreline, and 418 inland lakes. It is within a day's drive of Green Bay, Milwaukee, Chicago, Detroit, Minneapolis/St. Paul, and hundreds of other smaller communities. The combination of outstanding natural resources and closeness to highly populated regions has made the Hiawatha an important recreational attraction. Because the average snowfall ranges from 54 inches on the Forest's south shore to 240 inches or more on its north shore, people engage in winter sports here for nearly half of the year, primarily cross-country skiing, snowmobiling, ice fishing, hunting, and fur trapping.

Thomas Schmidt is a Research Forester in the Forest Inventory and Analysis Unit at the North Central Forest Experiment Station, St. Paul, Minnesota. He received a bachelor's degree in forest management in 1976 and a master's degree in forestry/land-use planning in 1981 from the University of MissouriColumbia. He received his Ph.D. in agronomy/ecology from the University of Nebraska-Lincoln in 1991 and joined the Forest Service in 1992.

Mike Lanasa is the Forest Silviculturist for the Hiawatha National Forest. He received a bachelor's degree in forest management in 1969 and a master's degree in silviculture in 1971 from West Virginia University. He joined the Forest Service in 1973 on the Monongahela National Forest in West Virginia.

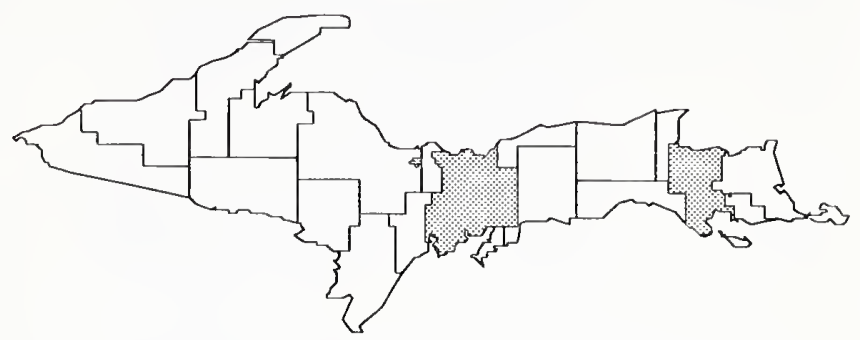

Figure 1.-Location of the Hiawatha National Forest in the Upper Peninsula of Michigan.

Three of the Great Lakes-Superior, Michigan, and Huron-have influenced the use of this peninsula by humans. This influence has been documented by archeology, by oral histories, and by the records of armies, missionaries, and governments. Native Americans influenced plant and animal communities through hunting, fishing, gathering, horticulture, and the use of fire. In the mid- to late-1800's, European immigration and resource exploitation caused major changes. Logging, and the fires that often followed, dramatically changed the area's vegetation. The current distribution, size, and abundance of various tree species are in many cases a direct result of these disturbances. However, the Hiawatha National Forest has recovered from these disturbances and today is entering a maturing stage.

Over the last five decades, the Forest Service has dedicated itself to managing National Forests with a multiple-use and sustained yield approach. However, an emerging global awareness and changes in society's expectations challenge us to re-examine this approach to resource management. As a result, we have shifted in focus from management of individual natural resources, such as timber, recreation, and wildlife, to management of the ecosystem and ecological landscapes of which those resources and species are a part. Ecosystem management on the Hiawatha National Forest is applied through five Ranger Districts located 
across six counties within the Forest (the Rapid River and Manistique Ranger Districts have been combined since this survey was completed).

\section{EXTENT OF FOREST LAND ON THE HLAWATHA NATIONAL FOREST}

Forested land occupies more than 823,700 acres of the Hiawatha National Forest, an increase of 6 percent since 1980. The remaining land is predominately marsh, bog, and upland openings. The Hiawatha's forest land is productive; more than 815,000 acres are capable of producing more than 20 cubic feet of wood per acre per year. The Hiawatha's forest land consists of 756,700 acres of timberland, 58,300 acres of reserved timberland, and 8,700 acres of unproductive woodlands. The timberland total includes 298,700 acres of forest land not allocated for timber production in the Forest Plan (see the Hiawatha National Forest Plan for detailed information about operational land-use categories). A redistribution in forest land area occurred in reserved timberland between 1980 and 1993. Six areas, ranging in size from 378 to 12,230 acres, were designated components of the National Wilderness Preservation System in 1987.

Caution: Standard forest inventory definitions are necessary to consolidate or compare information from across the country, but they can sometimes give a misleading impression. For example, an area need only have 16.7 percent stocking of forest trees of any size, or formerly have had such tree cover, to be categorized as forest land. Much land that meets this definition on the Hiawatha is being maintained in an open condition primarily for wildlife and biodiversity reasons.

Most impressions of the Upper Peninsula of Michigan are of tall pines and spruces towering over the landscape. However, this region has a wide variety of forest types containing diverse species. In fact, 14 different forest types were found on the Hiawatha National Forest in 1993. The Forest has about half of its timberland in deciduous forest types $(376,700$ acres) and about half in coniferous forest types $(380,000$ acres). Of the coniferous forests, 168,900 acres were in pines and 211,100 acres were in other conifers. This diversity of forest types is due to the variety of land forms, soils, succession, previous management efforts by the Forest, and a host of other influences.

There were several changes in forest types between inventories. From 1980 to 1993, northern white-cedar, aspen, jack pine, elmash-red maple, white spruce, and paper birch all decreased in area (fig. 2). Some of the decreases are due to forest succession, as with aspen and paper birch. Many of these early successional forests resulted from wildfires 50 to 100 years ago. If not regenerated by harvesting or fire, these short-lived types undergo succession and progress into other longer lived forest types. As an example, aspen decreased from 113,500 acres in 1980 to 81.300 acres in 1993. These acres stayed forested, but they underwent plant succession to the point where they were reclassified as other forest types such as maple-birch.

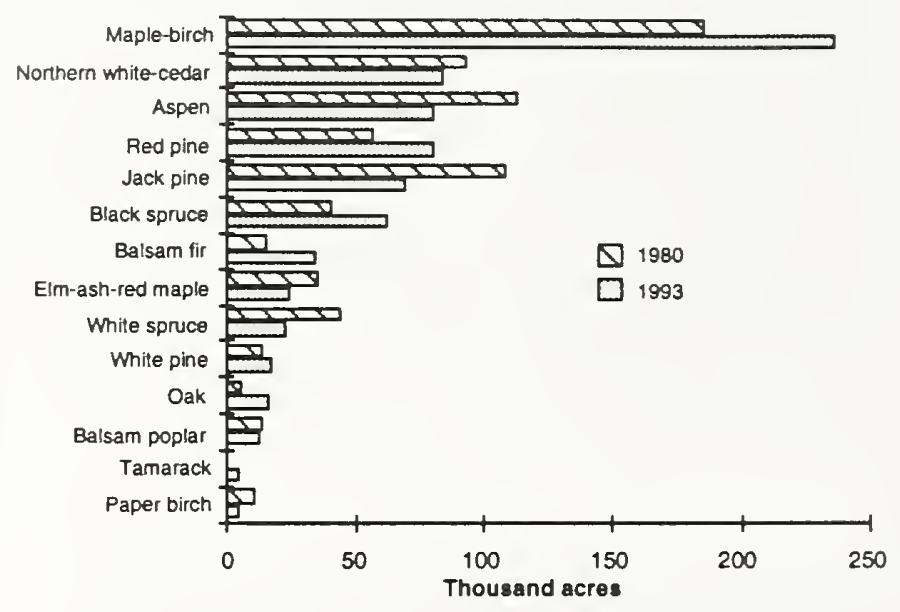

Figure 2.-Area of timberland by forest type on the Hiawatha National Forest, 1980 and 1993.

Early- to mid-successional forest types on the Hiawatha National Forest are jack pine, aspen, paper birch, and balsam poplar. Late successional forest types are red pine, white pine, white spruce, maple-birch, elm-ash-red maple, and oak. Swamp conifers, a third major kind of forest on the Hiawatha, include black spruce, balsam fir, northern white-cedar, and tamarack forest types.

Often, decreases in forest types, such as the elm-ash-red maple type, resulted from insects or diseases. Most of the larger elm trees on 
the Hiawatha have been killed by the Dutch elm disease, and as a result, many of these stands have been reclassified to the maplebirch forest type. A similar decrease occurred with white spruce as a result of spruce budworm infestations. Many of the areas that had been spruce regenerated to the balsam fir forest type. The decrease in northern whitecedar is a concern on the Hiawatha. Some of the harvested northern white-cedar stands have regenerated to other forest types such as balsam fir, spruce, or balm-of-Gilead as a result of either browsing by an increasing deer herd, or inadequate site preparation. The Forest has intensified efforts to regenerate northern white-cedar.

Succession also led to decreases in certain forest types and increases in other types. In 1980, early- to mid-successional forest types accounted for 33 percent, late successional types accounted for 46 percent, and swamp conifers accounted for 20 percent of the timberland on the Forest (fig. 3). By 1993, the area occupied by those early- to mid-successional forest types had decreased to 22 percent, while the area occupied by late-successional forest types had increased to more than 53 percent. Swamp conifers increased to 25 percent of timberland between inventories.

\section{COMIPOSITION OF THE HIAWATHA'S FORESTS}

The Hiawatha's forests contain more than $\mathbf{5 5}$ tree species and hundreds of other plants such

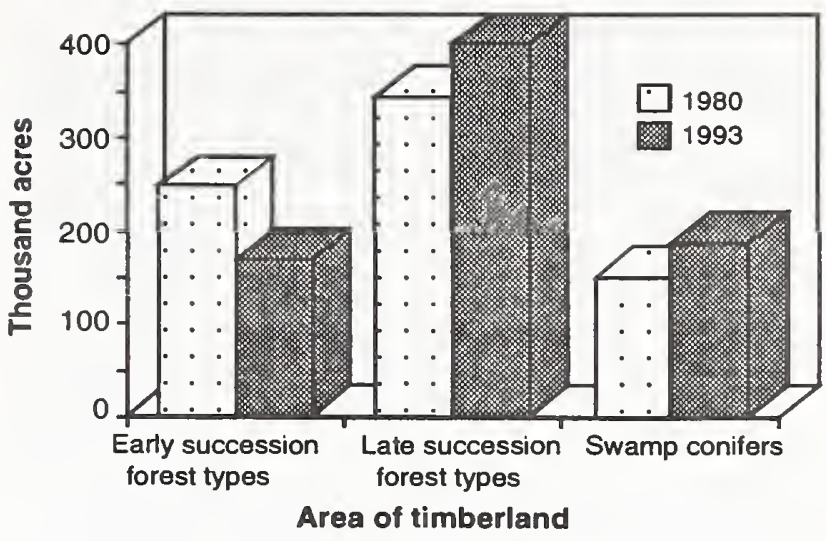

Figure 3.-Area of timberland by successional stage on the Hiawatha National Forest, 1980 and 1993.

as forbs, grasses, mosses, lichens, and sedges. The overstory woody plants dominate most sites and have a great influence on the existence of many of the understory plants. A tree is considered a woody plant having a perennial stem, a more or less definitely formed crown, and a height of at least $\mathbf{1 2}$ feet at maturity. In addition, to be counted in the total numbers of trees recorded in the inventory, a tree must have a d.b.h. of at least 1 inch. Northern white-cedar, with almost 74 million trees, was the predominant tree species in 1993 on the Hiawatha National Forest. Other common tree species were balsam fir, red maple, quaking aspen. sugar maple, black spruce, red pine, and jack pine (fig. 4). In total, there were almost 519 million trees on the Hiawatha in 1993, compared to 505 million trees in 1980.

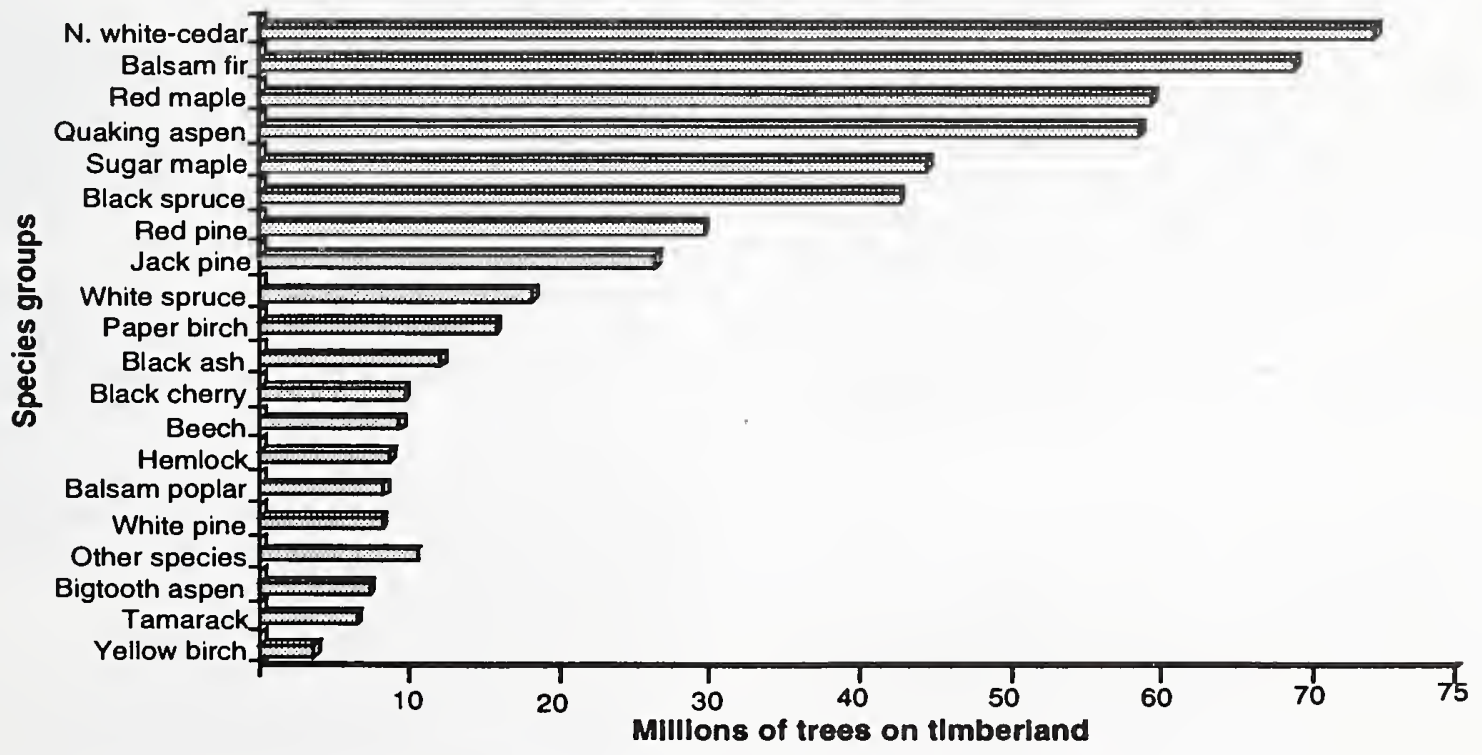

Figure 4.-Number of trees by species group on timberland on the Hiawatha National Forest, 1993. 
Forest inventories generally use three size classes to describe the forest resource based on the average diameter (d.b.h.) of the predominant trees: 1) young, recently established stands where the predominant trees are 1 to 5 inches (sapling/seedling): 2) mid-size, well-established stands where the predominant trees are 5 inches to either 9 inches for coniferous or 11 inches for deciduous species (poletimber); and 3) sawtimber stands with trees that are greater than 9 or 11 inches. In 1980, 20 percent of the timberland was in young stands, 53 percent was in mid-size stands, and 27 percent was in sawtimber stands (fig. 5). By 1993, 32 percent of the timberland was in young stands, 28 percent was in mid-size stands, and 40 percent was in sawtimber stands.

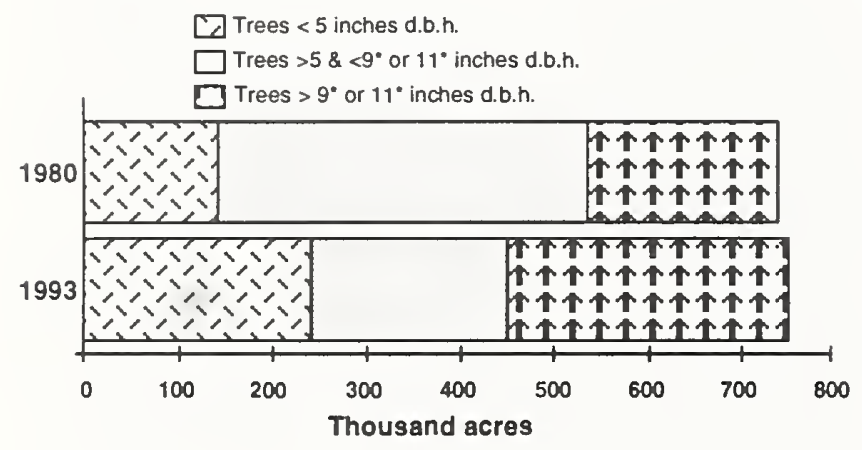

"Minimum classification is 9 inches for softwoods, 11 inches for hardwoods

Figure 5.-Area of timberland in 1980 and 1993 on the Hiawatha National Forest by stand-size class.

The area of sawtimber increased dramatically in several forest types. Red pine, northern whitecedar, and aspen all showed increases in this size class from 1980 to 1993 . There were some notable decreases as well. For example, white spruce decreased from 29,500 acres in 1980 to less than 5,000 acres in 1993 in the sawtimber size class. In total, there were about 940,000 trees more than 19 inches in diameter in 1980 . compared to more than 1.3 million in 1993. Most of the larger trees on the Hiawatha were white pine, hemlock, sugar maple, and beech.

Notable changes in mid-size stands occurred with decreases in every forest type except for the elm-ash-red maple type. Large increases occurred in the maple-birch, balsam fir, and red pine forest types between 1980 and 1993 in the young forest size class (seedlings/saplings).
In 1993,2 percent $(18,100$ acres) of the Hiawatha's timberlands were in either northern white-cedar or maple-birch stands older, on average, than 120 years. This does not include reserved forest land. In addition, scattered throughout the Hiawatha are individual trees that are at least 120 years old. These trees were not included in this classification because they did not dominate the stand to the level where they became the classified forest type.

The Hiawatha National Forest's net growingstock volume increased from 863 million cubic feet in 1980 to more than 1 billion cubic feet in 1993. Between inventories, net growing-stock volume for the jack pine, white spruce, yellow birch, elm, aspen, and paper birch species groups decreased by an average of 25 percent. All other species groups increased in net growing-stock volume. Red pine increased the most, rising from about 82 million cubic feet in 1980 to almost 151 million cubic feet by 1993-an 83 percent increase (fig. 6). In 1993, red pine, red maple, sugar maple, and northern white-cedar were the only species groups accounting for more than 100 million cubic feet of growingstock volume on the Hiawatha National Forest. These four species groups represented 50 percent of all volume on the Forest in 1993.

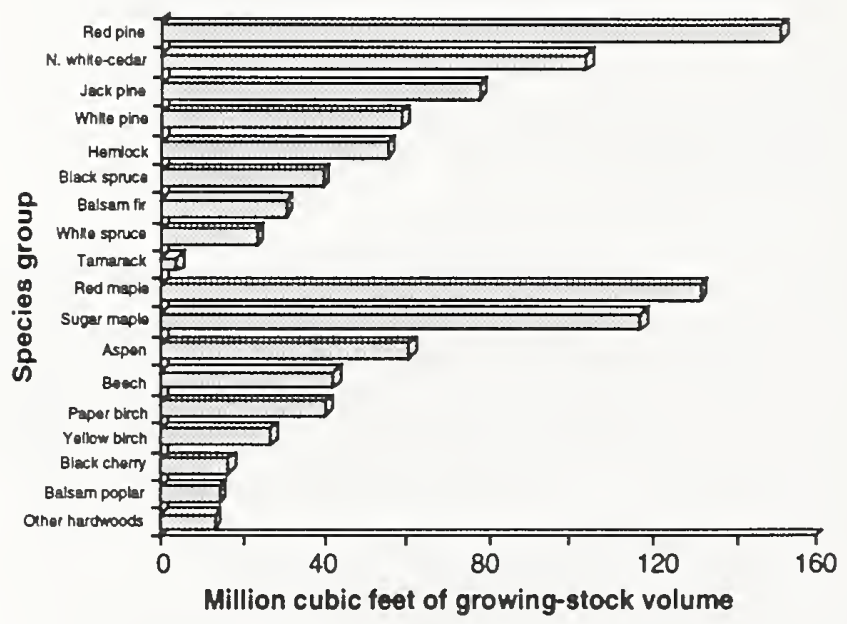

Figure 6.-Growing-stock volume by species group on timberland on the Hiawatha National Forest, 1993. 


\section{CAUSES OF CHANGE IN THE HIAWATHA'S FOREST RESOURCES}

Forests constantly act and react to both internal and outside influences. The primary purpose of a forest inventory is to document those changes and analyze their impact on the health and productivity of the forest. Specific data elements of a forest inventory used to document change include growth, mortality, and removals.

\section{Growth}

Total annual gross growth on the Hiawatha National Forest averaged more than $\mathbf{3 4}$ million cubic feet for growing stock and more than 118 million board feet of sawtimber between 1980 and 1992 (fig. 7). (Caution: do not add the two growth figures because they are not cumulative; growing-stock growth includes sawtimber growth because sawtimber is considered as a part of growing stock.) Annual mortality averaged about 8 million cubic feet for growing stock and 18 million board feet for sawtimber.

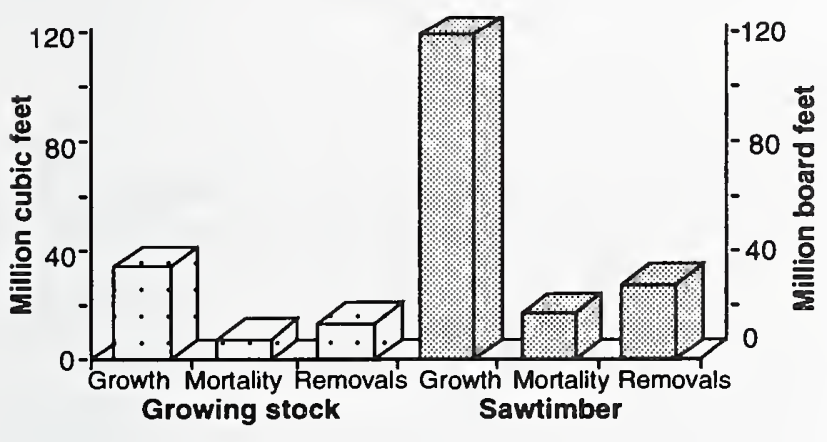

Figure 7.-Annual gross growth, mortality, and removals of growing stock and sawtimber on timberland on the Hiawatha National Forest between 1980 and 1993.

In addition, 13 million cubic feet of growing stock and 28 million board feet of sawtimber were removed from the Hiawatha annually between 1980 and 1992 . When mortality and removals were subtracted from gross growth, the net increase in total volume on the Hiawatha averaged more than 13 million cubic feet of growing stock and 73 million board feet of sawtimber each year between 1980 and 1992 . On the average acre on the Hiawatha, there was a net increase, after all mortality and removals were subtracted, of 18 cubic feet of growing stock per year. The growth to drain ratios (comparing growth to a combination of mortality and removals) average 2:1 for growing stock and more than 3:1 for sawtimber between 1980 and 1992, showing that the Hiawatha's forests are healthy and growing.

Conifers accounted for 62 percent of the average net annual growth (gross growth minus mortality) for growing stock between 1980 and 1993. Red pine alone accounted for 26 percent of all net growth on the Hiawatha between 1980 and 1992. Red and sugar maple were responsible for most of the growing-stock growth of deciduous species on the Hiawatha. All major species groups had more growing-stock growth than mortality and removals combined (fig. 8).

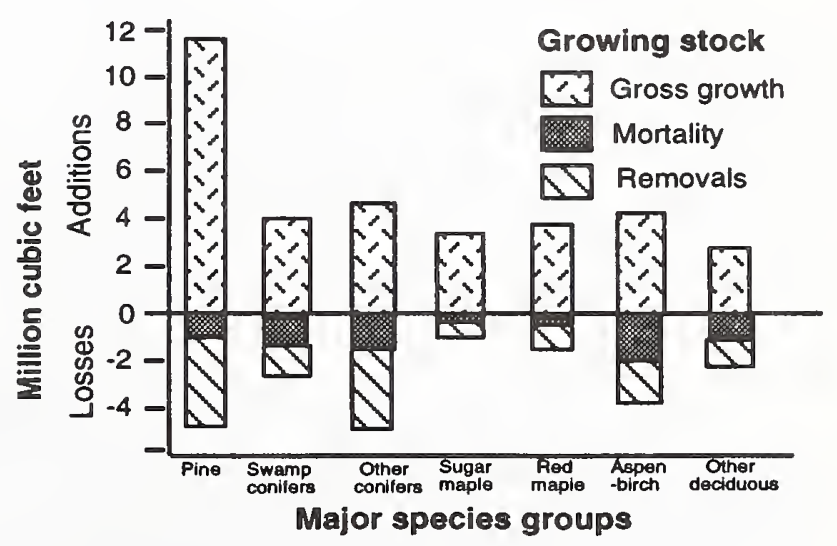

Figure 8.-Average annual gross growth, mortality, and removals for growing stock on timberland between 1980 and 1992 on the Hiawatha National Forest.

Sawtimber growth was similar to growing-stock growth; red pine showed the greatest growth. averaging more than $\mathbf{3 0}$ million board feet per year. White pine, sugar maple, and red maple all averaged between 9 and 10 million board feet of net growth per year on the Hiawatha. The pine species groups accounted for 46 percent of all net sawtimber growth, growing more than 46 million board feet per year (fig. 9).

\section{Mortality}

Average annual mortality on timberland on the Hiawatha National Forest was 23 percent of gross growth for growing stock and 15 percent for sawtimber. 


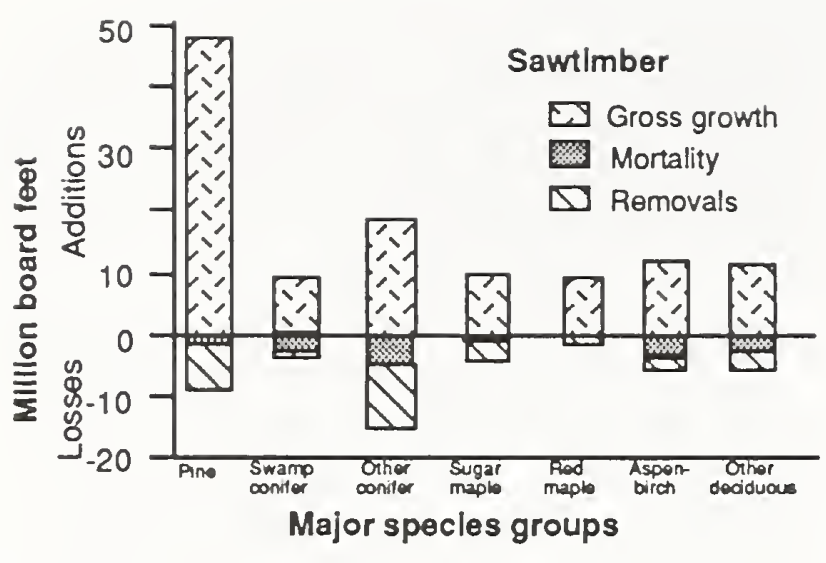

Figure 9.-Average annual gross growth, mortaltty. and removals on tumberland for sawtimber on the Hiawatha Nattonal Forest between 1980 and 1993.

Most of the known causes of growing-stock mortality were stem decay, wind, white trunk rot, Dutch elm disease, nectria canker, bole borers, porcupines, and weather-related factors such as flooding.
In addition to tree mortality, some trees are damaged by insects, diseases, and abiotic factors but do not die. Frequently, the result of these agents are cracks, holes, and crooks in and on the tree, which lower the value of the tree for timber but can raise the value of the tree for wildlife. For example, many species of wildlife rely on decay fungi to create rotten pockets in older trees that can then be used for nesting as well as for feeding and roosting.

\section{Removals}

Average annual growing-stock removals of more than 1 million cubic feet per year on timberland occurred in the white spruce. Jack pine, red pine, aspen, and red maple species groups. Sawtimber removals were highest for these same species groups plus white pine, yellow birch, sugar maple, and paper birch. These findings reflect harvesting for a wide variety of forest products. Harvesting, an important management aspect on the Hiawatha National Forest, contributes significantly to both the local and regional economies as well as to the lifestyle of the residents of the Upper Peninsula.

\section{APPENDIX}

Note: The 1993 inventory represents the fifth inventory of this region's forest resource. The four previous forest resource tnventorles are dated 1935, 1955, 1966, and 1980. Data from new forest tnventories are often compared with data from earlier inventories to determine trends in forest resources. However, for the compartsons to be valid, the procedures used in the two inventories must be similar. As a result of our ongoing efforts to improve the inventory's efficlency and reliablity. we have made several changes in procedures and definitions since the last Michigan inventory in 1980. Because some of these changes make it inappropriate to directly compare the 1993 data with those published for 1980. data from the 1980 inventory have been re-processed using the current procedures. Forest inventories completed before 1980 have not been adjusted to reflect current FLA inventory methodology and techniques. Comparisons between inventorles should be general and used solely for analyzing trends. All area and volume data and tables were based on what existed as of January 1, 1993, in the Hiawatha Nattonal Forest. The time perlod used for growth mortality. and removals was January 1, 1980, to
December 31, 1992. The data in this report are subject to change; however, it is expected that any such changes will be minor.

\section{Accuracy of the Survey}

Forest Inventory and Analysis (FIA) information is based on a sampling procedure. Consequently, the reported figures are estimates only. A measure of reliability of these figures is given by sampling errors. The level of sampling error used by FIA means the chances are two out of three that if a 100-percent inventory had been taken, using the same methods, the results would have been within the limits indicated. For example, the estimated growing-stock volume in the Hiawatha National Forest in 1993, 1,020.2 million cubic feet, has a sampling error of \pm 4.46 percent $( \pm 45.5$ million cubic feet). Based on this sampling error, growingstock volume from a 100 -percent inventory would be expected to fall between 974.7 and $1,065.7$ million cubic feet, there being a one in three chance that this is not the case. The sampling errors for the forest inventory of the Hiawatha National Forest in 1993 were: 
item

Unit totais

Million cublc feet $1,020.2$

26.5

7.69

(1980-1992)

Average annual removals

(1980-1992)

Sawtimber

Volume (1993)

Milllon board feet

$2,759.5$

18.61

Average annual growth

(1980-1992)

100.6

Average annual removals

(1980-1992)

Area

27.9

Thousand acres

Timberland (1993)

756.7

Care must be taken when using data from below the National Forest level because of increased sampling errors. For example, the sampling error for timberland area in a District or Management Area is higher than that for timberland area in the total National Forest. This tabulation shows the sampling errors for National Forest totals. To estimate sampling error for data smaller than National Forest totals, use the following formula:

Error $=$

(SE) $\sqrt{\text { (National Forest total area or volume) }}$

$\sqrt{\text { Volume or area smaller than National Forest }}$ total)

where: $\mathrm{E}=$ sampling error in percent

$\mathrm{SE}=$ National Forest total error for area

or volume.

For example, to compute the error on the area of timberland in the maple-birch type for the National Forest:

1. Total area of timberland in the maplebirch forest type from table $3=236,100$ acres;

2. Total area of all timberland in the National Forest from table $3=756,700$ acres:

3. National Forest total error for timberland area from the above tabulation $=2.45$ percent.

Using the above formula:

(2.45 percent) $\quad \sqrt{(756,700)}$

E

$=\frac{}{\sqrt{(236,100)}}= \pm 4.39$ percent.

\section{Survey Procedures}

The 1993 survey of the Hiawatha National Forest used a growth model-enhanced, twophase sample design. Using this sampling scheme and associated estimators is similar to sampling with partial replacement, in that a set of randomly located plots is avallable for remeasurement and a random set of new plots is established and measured. A significant feature of the design is stratification for disturbance on the old sample and use of a growth model to improve regression estimates made on old undisturbed forest plots (fig. 10). Detailed descriptions of the sampling and estimation procedures are presented by Hansen (1990). The growth model used was the Lake States Stand and Tree Evaluation and Modeling System (STEMS) (Belcher et al. 1982).

\section{Major Steps in the Survey Design}

\section{Aerlal photography (Phase 1)}

In this phase, two sets of random points were located on current aerial photographs. The first set was new photo plots, and the second set was relocated, old ground plot locations from the 1980 inventory. Locations of the plots used in the 1980 inventory were transferred to the new photographs. The photographs were then assembled into township mosaics, and a systematic grid of 121 one-acre photo plots (each plot representing approximately 190.4 acres) was overlaid on each township mosalc. Each photo plot was examined by aerlal photogrammetrists and classified stereoscopically as to its land use. If trees were present, forest type and stand-size/density classes were recorded. All of the 1980 ground plot locations were also examined for disturbance (logging, fire, catastrophic mortality, etc.). After this examination, all the old "disturbed" sample locations and one-third of the old "undisturbed" forested plots were sent to the field for survey crews to verify the photo classification and to take further measurements. All photo plot locations for the 1993 inventory were examined and classified as shown in the tabulation on the following page. 


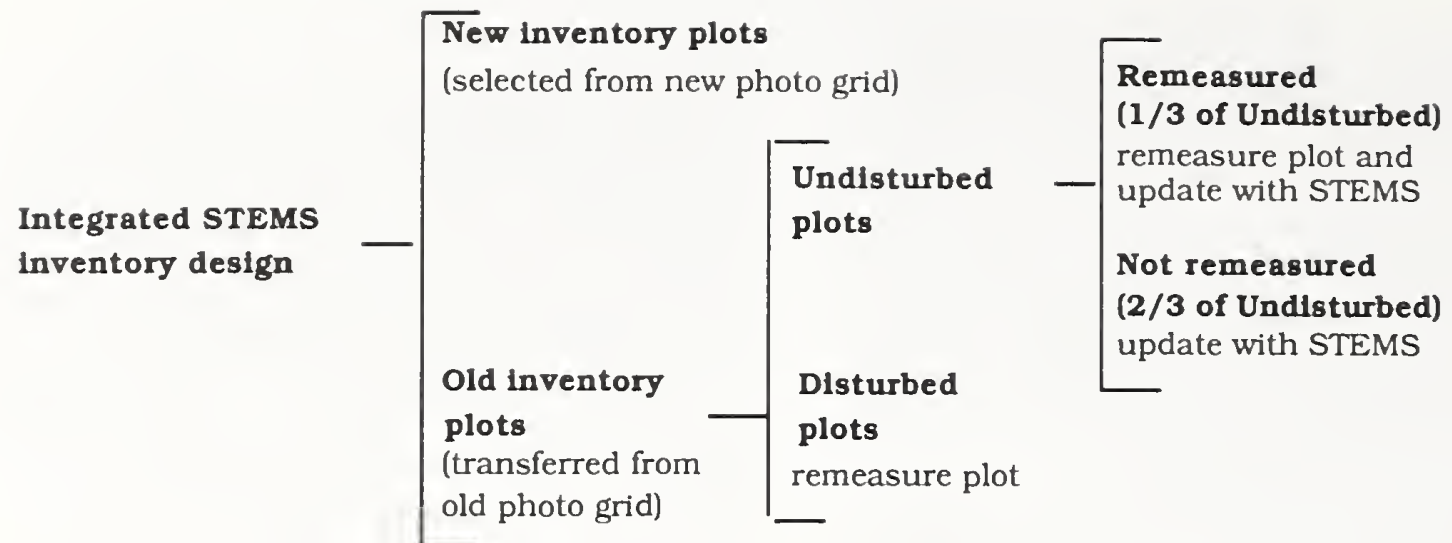

Figure 10.-Sample design for the Hiawatha National Forest 1993 survey.

\begin{tabular}{lc} 
Photo land class & Photo plots \\
Timberland & 3,919 \\
Reserved forest land & 218 \\
Other forest land & 0 \\
Questionable & 243 \\
Nonforest with trees & 74 \\
Nonforest without trees & 285 \\
Water & 0 \\
\multicolumn{1}{l}{ All classes } & 4,739
\end{tabular}

\section{Plot measurements (Phase 2)}

On plots classified as timberland, wooded pasture, or windbreak (at least 120 feet wide), a ground plot was established, remeasured, or modeled. Old plots that could not be relocated by field crews were replaced with a new plot at the approximate location of the old one. Each ground plot consisted of a 10-point cluster covering 1 acre. At each point, trees 5.0 inches or more d.b.h. were sampled on a 37.5 basal area factor variable-radius plot, and trees less than 5.0 inches d.b.h. were sampled on a 1/300-acre fixed-radius plot. The measurement procedure for both the new and old sample locations was:

\section{a. New inventory plots}

A random sample of new photo plots was selected for field measurement. Ground plots were established, and measures of current classification such as forest type, ownership. and size and condition of all trees on the plot. were recorded. These locations were monumented for future remeasurement. b. Old inventory plots

These plots were originally established, monumented, and measured as part of the 1980 field inventory. Procedures for these old plots were different from those for the new plots. Old plots were classed as "undisturbed" or "disturbed" in the aerial photo phase of the sampling process. All disturbed plots and a onethird sample of the undisturbed forested plots were remeasured to obtain estimates of current condition and changes since the last inventory. All trees measured on these plots in 1980 were remeasured or otherwise accounted for, and all new trees were identified and measured.

All sample plots that were forested at the time of the 1980 inventory and determined to be undisturbed until the 1993 inventory were projected to 1993 using STEMS. This procedure gives projected estimates of current volume and growth for undisturbed plots. Comparison of the projected and observed values on the onethird sample of the undisturbed forest plots that were remeasured provided local calibration data to adjust the projected values of the undisturbed plots that were not remeasured. The adjustment procedure is a modified version of the method described by Smith (1983).

Undisturbed forested plots that were not remeasured played a crucial role in the new survey design. These plots, after careful comparison of past and current aerial photography, were determined to be undisturbed and had conditions that could be simulated by STEMS. The STEMS growth model was used to "grow" 
the old plot and tree data to produce an estimate of current data. Thus, these plots were treated as ground plots, even though they were never visited. The plot record for each modeled plot was sent to the field for verification of current ownership information. All old plots classifled as disturbed were sent to the field for remeasurement to assess and verify changes since the last inventory. Disturbance referred to any change on a plot that was detected on aerial photos and that the STEMS growth processor could not predict, such as catastrophic mortality, cutting, seedling stands, and/or land use change.

The estimation procedure for computing statistics from this sampling design was more complicated than the simple two-phase estimation procedure used in the past. In fact, this procedure yielded two independent samples, one coming from the new photo points and the other from the old photo points that were remeasured or modeled. The following tabulation summarizes the distribution of all ground plots for the new inventory design by type of plot:

\section{Ground land use class}

Timberland Reserved forest land Nonforest with trees Nonforest without trees Total

\begin{tabular}{c}
$\begin{array}{c}\text { Old plots } \\
\text { remeasured }\end{array}$ \\
$\begin{array}{c}\text { Old p } \\
122\end{array}$ \\
13 \\
0 \\
2 \\
\hline 137
\end{tabular}

equation presented was used in conjunction with Hahn's board foot volume equation (Hahn 1984) to estimate gross volume. This estimate was then corrected by species for variation in bark and cull volume to yield an estimate of net volume.

The Forest Service reports all board foot volume in International 1/4-inch rule. In Michigan, the Scribner log rule is commonly used. Scribner log rule conversion factors were derived from full tree measurements taken throughout the Lake States (Michigan. Wisconsin, and Minnesota) and an equation developed by Wiant and Castenaeda (1977). Factors, or multipliers, that can be used to convert board foot International volumes to the Scribner rule are shown in the tabulation below:

\section{Area estimates}

Area estimates were made using two-phase estimation methods. In this type of estimation, a preliminary estimate of area by land use is made from the aerial photographs (Phase 1) and corrected by the plot measurements (Phase 2). A complete description of this estimation method is presented by Loetsch and Haller (1964).

\section{Volume estimates}

Estimates of volume per acre were made from the trees measured or modeled on the 10-point plots. Estimates of volume per acre were multiplied by the area estimates to obtain estimates of total volume. Net cubic foot volumes were based on a modification of the method presented by Hahn (1984) for use in the Lake States. The merchantable height

\begin{tabular}{ccc}
$\begin{array}{c}\text { D.B.H. } \\
\text { (Inches) }\end{array}$ & \multicolumn{2}{c}{ Scrlbner rulle converslon factor } \\
\cline { 2 - 3 } & Softwoods & Hardwoods \\
$9.0-10.9$ & 0.7830 & - \\
$11.0-12.9$ & .8287 & 0.8317 \\
$13.0-14.9$ & .8577 & .8611 \\
$15.0-16.9$ & .8784 & .8827 \\
$17.0-18.9$ & .8945 & .8999 \\
$19.0-20.9$ & .9079 & .9132 \\
$21.0-22.9$ & .9168 & .9239 \\
$23.0-24.9$ & .9240 & .9325 \\
$25.0-26.9$ & .9299 & .9396 \\
$27.0-28.9$ & .9321 & .9454 \\
$29.0+$ & .9357 & .9544
\end{tabular}




\section{Growth and mortality estimates}

On remeasured plots, estimates of growth and mortality per acre come from the remeasured dlameters of trees and from observation of trees that died between inventorles. Growth reported as the average net annual growth between the two inventories (1980 and 1992) was computed from data on remeasurement plots and modeled plots using methods presented by VanDeusen et al. (1986). Mortality was also reported as average annual for the remeasurement period. On new plots, where trees were not remeasured, estimates of growth and mortality were obtained by using STEMS to project the growth and mortality of trees for 1 year. Growth and mortality estimates for old undisturbed plots that were updated were derlved in the same manner as remeasured plots. The STEMS growth model was adjusted to meet local conditions, using data from the undisturbed remeasurement plots. As with volume, total growth and mortality estimates were obtained by multiplyIng the per acre estimates by area estimates. Current annual growth for 1992 was computed by using the adjusted STEMS model to grow all current inventory plots for 1 year.

\section{Average annual removals estimates}

Average annual growing-stock and sawtimber removals (1980 to 1992) were estimated only from the remeasured plots; new plots were not used to estimate removals. These estimates are obtained from trees measured in the last survey and cut or otherwise removed from the timberland base. Because remeasurement plots make up about one-half of the total ground plots, average annual removals est1mates have greater sampling errors than volume and growth estimates.

\section{Tree and Log Grades}

On approximately one-third of the sample plots in the Hiawatha National Forest, all sawtimber sample trees were graded for quality and assigned either a tree grade (hardwoods) or a log grade (softwoods). Tree and log grades were based on the evaluation of external characteristics as indicators of quality. The volume yield by grade for this sample was used to distribute the volume of the ungraded sample trees by species group. Red pine and jack pine sawtimber trees were graded based on speciflcations described in "Forest Service log grades for southern pines" (Campbell 1964). White pine and other softwood sawtimber trees were graded according to speciflcations described in "Sawlog grades for eastern white pine" (Ostrander and Brisbin 1971). For all softwoods, the first merchantable 16-foot log, or shorter lengths down to 12 feet, was used for grading. Hardwood sawtimber trees were graded according to "Hardwood tree grades for factory lumber" (Hanks 1976). The best 12-foot section of the lowest 16-foot hardwood log was used for grading. Hardwood sawtimber trees that did not meet minimum tree grade specifications for grades 1 through 3 were assigned grade 4 according to Forest Service standard specifications for hardwood construction logs described in "A guide to hardwood log grading" (Rast et al. 1973). 


\section{Log Grades for Jack Pine and Red Pine ${ }^{a}$}

Grade 1: Logs with three or four clear faces on the 16-foot grading section. b

Grade 2: Logs with one or two clear faces on the 16-foot grading section.

Grade 3: Logs with no clear faces on the 16-foot grading section.

After the tentative grade is established from above, the log will be reduced one grade for each of the following defects, except that no log can be reduced below grade 3. Net scale after deduction for defect must be at least 50 percent of the gross contents of the log.

1. Sweep. Degrade any tentative grade 1 or 2 log one grade if sweep amounts to 3 or more inches and equals or exceeds one-third of the diameter inside bark at the small end.

2. Heart rot. Degrade any tentative grade 1 or 2 log one grade if conk, punk knots, massed hyphae, or other evidence of advanced heart rot is found anywhere on the log.

a (Campbell 1964)

b A face is one-fourth of the circumference in width extending full length of the log. Clear faces are those free of: knots measuring more than one-half inch in diameter, overgrown knots of any size, and holes more than onefourth inch in diameter. Faces may be rotated to obtain the maximum number of clear ones.

\section{Log Grades for All Other Softwood Logs}

\section{Grade 1}

1. Logs must be 16 inches d.i.b. or larger, 10 feet in length or longer, and with deduction for defect, not over 30 percent of gross scale.

2. Logs must be at least 75 percent clear on each of three faces.

3. All knots outside clear cuttings must be sound and not more than $2-1 / 2$ inches in size.

Grade 2

1. Logs must be 12 inches d.i.b. or larger, 10 feet in length or longer, and with a net scale after deduction for defect of at least 50 percent of the gross contents of the log.

2. Logs must be at least 50 percent clear on each of three faces or 75 percent clear on two faces.

\section{Grade 3}

1. Logs must be 6 inches d.i.b. or larger, 8 feet in length or longer, and with a net scale after deduction for defect of at least 50 percent of the gross contents of the log.

Note: Diameters are d.i.b. at small end of grading section; percent clear refers to percent clear in one continuous section. 
Eastern White Pine Saw-log Grade Specifications a

\begin{tabular}{|c|c|c|c|c|}
\hline Grading factor & Log grade 1 & Log grade 2 & Log grade 3 & Log grade 4 \\
\hline $\begin{array}{l}\text { 1. Minimum scaling } \\
\text { diameter (inches) }\end{array}$ & $14^{b}$ & 年 & 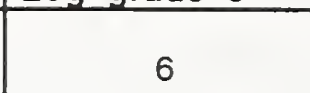 & - y grum \\
\hline $\begin{array}{l}\text { 2. Minimum log length } \\
\text { (feet) }\end{array}$ & $10^{C}$ & 8 & 8 & 8 \\
\hline $\begin{array}{l}\text { 3. Maximum weevil } \\
\text { injury (number) }\end{array}$ & None & None & 2 injuries $d$ & No limit \\
\hline $\begin{array}{l}\text { 4. Minimum face } \\
\text { requirements }\end{array}$ & $\begin{array}{l}\text { Two full length } \\
\text { or four } 50 \% \text { e } \\
\text { length good } \\
\text { faces (in } \\
\text { addition, log } \\
\text { knots on } \\
\text { balance of } \\
\text { faces shall not } \\
\text { exceed size } \\
\text { limit of grade } \\
2 \text { logs). }\end{array}$ & $\begin{array}{l}\text { SOUND } \\
\text { not to exceed } 1 / \\
\text { scaling diameter } \\
\text { and } 3 " \text { maximum } \\
\text { OVERGROWN/ } \\
\text { not to exceed } \\
1 / 12 \text { scaling } \\
\text { diameter and } \\
11 / 2 " \text { max. }\end{array}$ & $\begin{array}{l}\text { CES REQUIRED } \\
\text { ter of log knots on } \\
\text { best faces: } \\
\text { ED KNOTS } \\
\text { not to exceed } 1 / 3 \\
\text { scaling diameter } \\
\text { and } 5^{\prime \prime} \text { maximum } \\
\text { AD/BLACK KNOTS } \\
\text { not to exceed } \\
1 / 6 \text { scaling } \\
\text { diameter and } \\
21 / 2 " \text { max. }\end{array}$ & $\begin{array}{l}\text { Includes all logs } \\
\text { not qualifying for } \\
\text { No. } 3 \text { or better } \\
\text { and have at least } \\
1 / 3 \text { of their } \\
\text { gross volume in } \\
\text { sound wood } \\
\text { suitable for } \\
\text { manufacture } \\
\text { into standard } \\
\text { lumber }\end{array}$ \\
\hline $\begin{array}{l}\text { 5. Maximum sweep or } \\
\text { crook }(\%)\end{array}$ & 20 & 30 & 40 & $662 / 3$ \\
\hline $\begin{array}{l}\text { 6. Maximum total } \\
\text { scaling deduction } \\
(\%)\end{array}$ & 50 & 50 & 50 & $662 / 3$ \\
\hline
\end{tabular}

AFTER THE TENTATIVE LOG GRADE IS ESTABLISHED FROM FACE EXAMINATION, THE LOG WILL BE REDUCED IN GRADE WHENEVER THE FOLLOWING DEFECTS ARE EVIDENT

7. Conks, punk knots, and pine borer damage on bark surface. ${ }^{f}$

Degrade one grade if present on one face.

Degrade two grades if present on two faces.

Degrade three grades if present on three or more faces.

8. Log end defects: red rot, ring shake, heavy stain, and pine borer damage outside the heart center of

log. ${ }^{f}$ Consider log as having a total of 8 quarters ( 4 on each end) and degrade as indicated.

Degrade one grade if present in 2 quarters of log ends.

Degrade two grades if present in 3 or 4 quarters of log ends.

Degrade three grades if present in 5 or more quarters of log ends.

a. (Ostrander and Brisbin 1971)

b. 12- and 13-inch logs with four full-length good faces are acceptable.

c. 8-foot logs with four full-length good faces are acceptable.

d. 8-foot Number 3 logs limited to one weevil injury.

e. Minimum $50 \%$ length good face must be at least 6 feet.

f. Factors 7 and 8 are not cumulative (total degrade based on more serious of the two). No log is to be degraded below grade 4 if net scale is at least one-third of gross scale. 


\section{Hardwood Tree Grades for Factory Lumber a}

\begin{tabular}{|c|c|c|c|}
\hline Grade factor & $\begin{array}{c}\text { Tree } \\
\text { grade } \\
1\end{array}$ & $\begin{array}{c}\text { Tree } \\
\text { grade } \\
2\end{array}$ & $\begin{array}{c}\text { Tree } \\
\text { grade } \\
3\end{array}$ \\
\hline Length of grading zone (feet) & Butt 16 & Butt 16 & Butt 16 \\
\hline Length of grading section $b$ (feet) & Best 12 & Best 12 & Best 12 \\
\hline D.b.h., minimum (inches) & $16^{C}$ & 13 & 11 \\
\hline $\begin{array}{l}\text { Diameter, minimum inside bark at top of } \\
\text { grading section (inches) }\end{array}$ & $13^{C} \quad 1620$ & $11^{\mathrm{d}} \quad 12$ & 8 \\
\hline $\begin{array}{l}\text { Clear cuttings (on the } 3 \text { best faces): } \\
\text { Length, minimum (feet) } \\
\text { Number on face (maximum) } \\
\text { Yield in face length (minimum) }\end{array}$ & $\begin{array}{c}75 \\
2 \\
5 / 6\end{array}$ & $\begin{array}{lr}3 & 3 \\
2 & 3\end{array}$ & $\begin{array}{c}2 \\
f \\
3 / 6\end{array}$ \\
\hline $\begin{array}{l}\text { Cull deduction (including crook and sweep, } \\
\text { but excluding shake) maximum within } \\
\text { grading section (percent) }\end{array}$ & 9 & 99 & 50 \\
\hline
\end{tabular}

a (Hanks 1976)

b Whenever a 14- or 16-foot section of the butt 16-foot log is better than the best 12-foot section, the grade of the longer section will become the grade of the tree. This longer section, when used, is the basis for determining the grading factors.

c In basswood and ash, diameter inside bark (d.i.b.) at top of grading section must be 12 inches and d.b.h. must be 15 inches.

d Grade 2 trees can be 10 inches d.i.b. at top of grading section if otherwise meeting surface requirements for small grade 1 's.

e A clear cutting is a portion of a face free of defects, extending the width of the face. A face is onefourth of the surface of the grading section as divided lengthwise.

f Unlimited.

g Fifteen percent crook and sweep or 40 percent total cull deduction are permitted in grade 2, if size and surface of grading section qualify as grade 1 . If rot shortens the required clear cuttings to the extent of dropping the butt log to grade 2, do not drop the tree's grade to 3 unless the cull deduction for rot is greater than 40 percent. 


\section{Forest Service Standard Specifications for Hardwood Construction Logs Tie and Timber logs $a b$}

\begin{tabular}{c|l}
\hline Position in tree & Butts and uppers \\
\hline Minimum diameter, small end & 8 inches + \\
\hline Minimum length without trim & 8 feet + \\
\hline Clear cuttings & No requirements \\
\hline Sweep allowance & $\begin{array}{l}\text { One-fourth small end d.i.b. for each } 8 \text { feet of length. One-half d.i.b. } \\
\text { for logs } 16 \text { feet long. }\end{array}$ \\
\hline Sound surface defects: & $\begin{array}{l}\text { Any number, if no knot has an average diameter above the callus in } \\
\text { excess of one-third of the log diameter at point of occurrence. }\end{array}$ \\
\hline Single knots & $\begin{array}{l}\text { Any number, if the sum of knot diameters above the callus does not } \\
\text { exceed one-third of the log diameter at point of occurrence. }\end{array}$ \\
\hline Whorled knots & $\begin{array}{l}\text { Any number not exceeding knot specifications as long as they do not } \\
\text { extend over } 3 \text { inches into contained tie or timber. }\end{array}$ \\
\hline Unsoles & $\begin{array}{l}\text { Same requirements as for sound defects if they extend into included } \\
\text { timber. No limit if they do not. }\end{array}$ \\
\hline Surface & $\begin{array}{l}\text { None permitted except one shake not more than one-third the width of } \\
\text { contained tie or timber, and one split, not over } 5 \text { inches. }\end{array}$ \\
\hline
\end{tabular}

a (Rast et al. 1973)

b These specifications are minimum for the class. If, from a group of logs, factory logs are selected first, thus leaving only nonfactory logs from which to select construction logs, then the quality range of the construction logs so selected is limited, and the class may be considered a grade. If selection for construction logs is given first priority, it may be necessary to subdivide the class into grades. 


\section{METRIC EQUIVALENTS OF UNITS USED IN THIS REPORT}

1 acre $=4,046.86$ square meters or 0.405

hectare.

1,000 acres $=405$ hectares.

1 cubic foot $=0.0283$ cubic meter.

1 foot $=30.48$ centimeters or 0.3048 meter .

1 inch $=25.4$ millimeters, 2.54 centimeters, or 0.0254 meter.

1 pound $=0.454$ kilogram .

1 ton $=0.907$ metric ton .

\section{TREE SPECIES IN THE HIAWATHA NATIONAL FOREST ${ }^{1}$}

\section{SOFTWOODS}

Balsam fir.... Abies balsamea

Tamarack . Larix laricina

White spruce Picea glauca

Black spruce Picea mariana

Jack pine

Pinus banksiana

Red pine Pinus resinosa

Eastern white pine Pinus strobus

Northern white-cedar Eastern hemlock

\section{HARDWOODS}

Sugar maple ${ }^{2}$

Red maple ${ }^{3}$ Acer saccharum

Yellow birch ${ }^{2}$

Paper birch ${ }^{3}$

Acer rubrum

American beech ${ }^{3}$

White ash ${ }^{2}$

Black ash ${ }^{3}$

Green ash ${ }^{2}$

Thuja occidentalis

Tsuga canadensis

Butternut $^{3}$

.....................

la

Balsam poplar ${ }^{3}$

Bigtooth aspen ${ }^{3}$

Guaking aspen ${ }^{3}$

Black cherry ${ }^{3}$

$n^{3}$

a...........

Swamp white oak ${ }^{2}$

Northern red oak ${ }^{2}$.

American basswood ${ }^{3}$

American $\mathrm{elm}^{3}$

Betula alleghaniensis Betula papyrifera

Fagus grandifolia Fraxinus americana Fraxinus nigra Fraxinus pennsylvanica Juglans cinerea Populus balsamifera Populus grandidentata Populus tremuloides Prunus serotina Quercus bicolor .Quercus rubra Tilia americana Ulmus americana

\footnotetext{
${ }^{1}$ The common and scientific names are based on Little, Elbert $L$.

${ }^{2}$ This species or species group is considered a hard hardwood, with an average specific gravity greater than or equal to 0.50 .

${ }^{3}$ This species or species group is considered a soft hardwood, with an average specific gravity of less than 0.50 .
}

Noncommercial species

Striped maple

Acer pennsylvanicum

Mountain maple Acer spicatum

Hawthorn . Crataegus spp.

Eastern hophornbeam........... Ostrya virginiana Canada plum .......................... Prunus nigra Pin cherry ...................... Prunus pensylvanica Wild plum ............................... Prunus spp. Chokecherry ......................Prunus virginiana Willow spp. Salix spp.

\section{DEFINITION OF TERMS}

\section{Average annual removals from growing} stock.-The average net growing-stock volume in growing-stock trees removed annually for forest products (including roundwood products and logging residues) and for other uses. Average annual removals of growing stock are reported for a period of several years (1980 through 1992 in this report) and are based on information obtained from remeasurement plots (see Survey Procedures in Appendix).

\section{Average annual removals from sawtimber.-} The average net board foot sawtimber volume of live sawtimber trees removed annually for forest products (including roundwood products) and other uses. Average annual removals of sawtimber are reported for a period of several years (1980 through 1992 in this report) and are based on information obtained from remeasurement plots (see Survey Procedures in Appendix).

\section{Average net annual growth of growing} stock.-The annual change in volume of sound wood in live sawtimber and poletimber trees and the total volume of trees entering these classes through ingrowth, less volume losses resulting from natural causes.

\section{Average net annual growth of sawtimber.-} The annual change in the volume of live sawtimber trees and the total volume of trees reaching sawtimber size, less volume losses resulting from natural causes.

Basal area.-Tree area, in square feet, of the cross section at breast height of a single tree. When the basal areas of all trees in a stand are summed, the result is usually expressed as square feet of basal area per acre. 
Butt log.-The first 12 to 16 feet from a 1 -foot stump that could be, or is, cut. Minimum standards for butt logs vary by species.

Clear panel.-A section of hardwood tree surface one-fourth the circumference of the tree and at least 2 feet long, free of limbs, knots, bumps, and other indications of defect that preclude clear cuttings.

Commercial species.-Tree species presently or prospectively suitable for industrial wood products. (Note: Excludes species of typically small size, poor form, or inferior quality such as hophornbeam, osage-orange, and redbud.)

Cull.-Portions of a tree that are unusable for industrial wood products because of rot, missing or dead material, or other defect.

Diameter class.-A classification of trees based on diameter outside bark, measured at breast height (d.b.h.). Two-inch diameter classes are commonly used in Forest Inventory and Analysis, with the even inch the approxdmate midpoint for a class. For example, the 6-inch class includes trees 5.0 through 6.9 inches d.b.h.

Dlameter at breast height (d.b.h.).-The outside bark diameter at 4.5 feet $(1.37 \mathrm{~m})$ above the forest floor on the uphill side of the tree. For determining breast height, the forest floor includes the duff layer that may be present, but does not include unincorporated woody debris that may rise above the ground line.

Face.-A section of the tree surface one-fourth the circumference of the tree extending the full length of the log.

Forest land.-Land at least 16.7 percent stocked by forest trees of any size, or formerly having had such tree cover, and not currently developed for nonforest use. (Note: Stocking is measured by comparing specifled standards with basal area and/or number of trees, age or size, and spacing.) The minimum area for classiflcation of forest land is 1 acre. Roadside, streamside, and shelterbelt strips of timber must have a crown width of at least 120 feet to qualify as forest land. Unimproved roads and trails, streams, or other bodies of water or clearings in forest areas shall be classed as forest if less than 120 feet wide.
(See definitions for Land. Timberland, Reserved forest land, Stocking, and Water.)

Forest type.-A classification of forest land based on the species forming a plurality of live tree stocking. Major forest types on the Hiawatha are:

Jack pine.-Forests in which jack pine comprises a plurality of the stocking. (Common associates include eastern white pine. red pine, aspen, birch, and maple.)

Red pine.-Forests in which red pine comprises a plurality of the stocking. (Common associates include eastern white pine, Jack pine, aspen, birch, and maple.)

Eastern white pine.-Forests in which eastern white pine comprises a plurality of the stocking. (Common associates include red pine, jack pine, aspen, birch, and maple.)

Balsam fir.-Forests in which balsam fir and white spruce comprise a plurality of stocking with balsam fir the most common. (Common associates include white spruce, aspen, maple, birch, northern white-cedar, and tamarack.)

White spruce.-Forests in which white spruce and balsam fir comprise a plurality of the stocking with white spruce the most common. (Common associates include balsam fir, aspen, maple, birch, northern whitecedar, and tamarack.)

Black spruce.-Forests in which swamp conifers comprise a plurality of the stocking with black spruce the most common. (Common assoctates include tamarack and northern white-cedar.)

Northern white-cedar.-Forests in which swamp conifer species comprise a plurality of the stockdng with northern white-cedar the most common. (Common associates include tamarack and black spruce.)

Tamarack.-Forests in which swamp conifers comprise a plurality of the stocking with tamarack the most common. (Common associates include black spruce and northern white-cedar.)

Oak-hickory.-Forests in which northern red oak, white oak, bur oak, or hickories, singly or in combination, comprise a plurality of the stocking. (Common associates include jack pine, beech, yellow-poplar, elm, and maple.)

Elm-ash-soft maple.-Forests in which lowland elm, ash, red maple, silver maple, and 
cottonwood, singly or in combination, comprise a plurality of the stocking. (Common associates include birch, spruce, and balsam fir.)

Maple-birch-Forests in which sugar maple, basswood, yellow birch, upland American elm, and red maple, singly or in comblnation, comprise a plurality of the stocking. (Common associates include birch, spruce. and balsam fir.)

Aspen-Forests in which quaking aspen or bigtooth aspen, singly or in combination. comprise a plurality of the stocking. (Common associates include balsam poplar. balsam fir, and paper birch.)

Paper btrch-Forests in which paper birch comprises a plurality of the stocking. (Common assoclates include maple, aspen, and balsam fir.)

Balsam poplar.-Forests in which balsam poplar comprises a plurality of the stocking. (Common associates include aspen, elm, and ash.)

Growing-stock tree.-A live tree of commerclal species that meets specified standards of size, quality, and merchantability. (Note: Excludes rough, rotten, and dead trees.)

Growing-stock volume.-Net volume in cubic feet of growing-stock trees 5.0 inches d.b.h. and over, from 1 foot above the ground to a minimum 4.0-inch top diameter loutside bark) of the central stem or to the point where the central stem breaks into limbs.

Hard hardwoods.--Hardwood species with an average specific gravity greater than 0.50 such as oaks, hard maple, and hickories.

Hardwoods.-Dicotyledonous trees, usually broad-leaved and deciduous. (See Soft hardwoods and Hard hardwoods.)

Land.-A. Bureau of the Census. Dry land and land temporarily or partly covered by water such as marshes, swamps, and river flood plains; streams and sloughs less than one-eighth of a statute mile wide; and lakes, reservoirs, and ponds less than 40 acres in area.

B. Forest Inventory and Analysis. The same as the Bureau of the Census, except minimum width of streams, etc., is 120 feet and minimum size of lakes, etc., is less than 1 acre.
Live trees.-Growing-stock, rough, and rotten trees 1.0 inch d.b.h. and larger.

Log grade.-A log classification based on external characteristics as indicators of quality or value. (See Appendix for specific grading factors used.)

Merchantable.-Refers to a pulpwood or sawlog section that meets pulpwood or saw-log specifications, respectively.

Mortality.-The volume of sound wood in growing-stock and sawtimber trees that die annually.

National Forest land.-Federal land that has been legally designated as National Forest or purchase units, and other land administered by the USDA Forest Service.

Net volume.-Gross volume less deductions for rot, sweep, or other defect affecting use for timber products.

Noncommerclal species.-Tree species of typically small size, poor form, or inferior quality that normally do not develop into trees suitable for industrial wood products. Classified in volume tables as rough trees.

Nonforest land.-Land that has never supported forests, and land formerly forested where use for timber management is precluded by development for other uses. (Note: Includes areas used for crops, improved pasture, residential areas, city parks, improved roads of any width and adjoining clearings, powerline clearings of any width, and 1- to 39.9- acre areas of water classified by the Bureau of the Census as land. If intermingled in forest areas, unimproved roads and nonforest strips must be more than 120 feet wide and more than 1 acre in area to quallfy as nonforest land.)

a. Nonforest land without trees.-Nonforest land with no live trees present.

b. Nonforest land with trees. - Nonforest land with one or more trees per acre at least 5 inches d.b.h.

Nonstocked land.-Forest land less than 16.7 percent stocked with live trees.

Poletimber stand.-(See Stand-size class.) 
Poletimber tree.-A tree of commerclal specles at least 5.0 inches d.b.h. but smaller than sawtimber size (9 inches d.b.h. for softwoods, 11 inches d.b.h. for hardwoods).

Potential productivity class.-A classiflcation of forest lands in terms of inherent capacity to grow crops of industrial wood. The class identifies the potential growth in merchantable cubic feet/acre/year at culmination of mean annual increment of fully stocked natural stands.

Reserved forest land.-Forest land withdrawn from timber utilization through statute, administrattve regulation, designation, or exclusive use for Christmas tree production, as indicated by annual shearing.

Rotten tree.-A tree that does not meet reglonal merchantabllity standards because of excesstve unsound cull.

Rough tree.-A tree that does not meet regional merchantabllity standards because of excesstve sound cull. May include noncommercial tree species.

Roundwood products.-Logs, bolts, or other round sections (including chips from roundwood) cut from trees for industrial or consumer uses. (Note: Includes saw logs, veneer logs, and bolts; cooperage logs and bolts; pulpwood; fuelwood; pllings; poles; posts; hewn ties; mine timbers; and various other round, split, or hewn products.)

Salvable dead tree.-A standing or down dead tree considered merchantable by regional standards.

Sapling.-A live tree 1.0 to 5.0 inches d.b.h.

\section{Sapllng-seedling stand.--(See Stand-size} class.)

Saw log.-A log meeting minimum standards of diameter, length, and defect. A saw log must be at least 8 feet long. sound. straight, have a minimum diameter outside bark (d.o.b.) of 7.0 inches for softwoods and 9.0 inches for hardwoods, or have other combinations of size and defect specifled by reglonal standards.
Saw-log portion. - That part of the bole of sawt mber trees between the stump and the saw-log top.

Saw-log top.-The point on the bole of sawtimber trees above which a saw log cannot be produced. The minimum saw-log top is 7.0 inches d.o.b. for softwoods and 9.0 inches d.o.b. for hardwoods.

\section{Sawtimber stand.-(See Stand-size class.)}

Sawtimber tree.-A tree of commercial species containing at least a 12-foot saw log or two noncontiguous saw logs 8 feet or longer, and meeting regional specifications for freedom from defect. Softwoods must be at least 9.0 inches d.b.h. Hardwoods must be at least 11.0 inches d.b.h.

Sawtimber volume. - Net volume of the saw-log portion of live sawtimber in board feet, International 1/4-inch rule (unless specifled otherwise), from the stump to a minimum 7inch top d.o.b. for softwoods and a minimum 9-inch top d.o.b. for hardwoods.

Seedling.-A ive tree less than 1.0 inch d.b.h. that is expected to survive. Only softwood seedlings more than 6 inches tall and hardwood seedlings more than 1 foot tall are counted.

Site index.-An expression of forest site quality based on the height of a free-growing dominant or codominant tree of a representative species in the forest type at age 50 .

Soft hardwoods. - Hardwood specles with an average specific gravity less than 0.50 such as gum, yellow-poplar, cottonwood, red maple. basswood, and willow.

Softwoods. - Coniferous trees, usually evergreen. having needles or scale-like leaves.

Stand.-A group of trees on a minimum of 1 acre of forest land that is stocked by forest trees of any size.

Stand-age class.-Age of main stand. Main stand refers to trees of the dominant forest type and stand-size class. 
Stand-size class.-A classification of stocked (see Stocking) forest land based on the size class of live trees on the area; that is, sawtimber, poletimber, or seedlings and saplings.

a. Sawtimber stands. - Stands with half or more of live stocking in sawtimber or poletimber trees, and with sawtimber stocking at least equal to poletimber stocking.

b. Poletimber stands. - Stands with half or more live stocking in poletimber and/or sawtimber trees, and with poletimber stocking exceeding that of sawtimber.

c. Sapling-seedling stands.-Stands with more than half of the live stocking in saplings and/or seedlings.

Stocking.-The degree of occupancy of land by live trees, measured by basal area; and/or the number of trees in a stand by size or age and spacing, compared to the basal area; and/or number of trees required to fully utilize the growth potential of the land; that is, the stocking standard.

A stocking percent of 100 indicates full utilization of the site and is equivalent to 80 square feet of basal area per acre in trees 5.0 inches d.b.h. and larger. In a stand of trees less than 5.0 inches d.b.h., a stocking percent of 100 would indicate that the present number of trees is sufficient to produce 80 square feet of basal area per acre when the trees reach 5.0 inches d.b.h.

Stands are grouped into the following stocking classes:

Overstocked stands. - Stands in which stocking of live trees is 133 percent or more.

Fully stocked stands.-Stands in which stocking of live trees is from 100.0 to 132.9 percent.

Medium stocked stands. - Stands in which stocking of live trees is from 60.0 to 99.9 percent.

Poorly stocked stands.-Stands in which stocking of live trees is from 16.7 to 59.9 percent.

Nonstocked areas.-Timberland on which stocking of live trees is less than 16.7 percent.

Timberland.-Forest land that is producing, or capable of producing, in excess of 20 cubic feet per acre per year of industrial wood crops under natural conditions. In addition, the forest land must not be withdrawn from timber utilization, and not associated with urban or rural development. Currently inaccessible and inoperable areas are included.

Tree.-A woody plant usually having one or more perennial stems, a more or less definitely formed crown of foliage, and a height of at least 12 feet at maturity.

Tree grade.-A tree classification based on external characteristics as indicators of quality or value, used for hardwood species. (See Appendix for specific grading factors used.)

Tree size class.-A classification of trees based on diameter at breast height, including sawtimber trees, poletimber trees, saplings, and seedlings.

Unproductive forest land.-Forest land incapable of producing 20 cubic feet per acre per year of industrial wood under natural conditions because of adverse site conditions.

(Note: Adverse conditions include sterile soils, dry climate, poor drainage, high elevation, steepness, and rockiness).

Upper stem portion.-That part of the bole of sawtimber trees above the saw-log top to a minimum top diameter of 4.0 inches outside bark, or to the point where the central stem breaks into limbs.

Water.-(a) Bureau of the Census.-Permanent inland water surfaces, such as lakes, reservoirs, and ponds at least 40 acres in area; and streams, sloughs, estuaries, and canals at least one-eighth of a statute mile wide.

(b) Noncensus.-Permanent inland water surfaces, such as lakes, reservoirs, and ponds from 1 to 39.9 acres in area; and streams, sloughs, estuaries, and canals from 120 feet to one-eighth of a statute mile wide.

\section{LITERATURE CITED}

Belcher, David W.; Holdaway, Margaret R.; Brand, Gary J. 1982. A description of STEMS the stand and tree evaluation and modeling system. Gen. Tech. Rep. NC-79. St. Paul, MN: U.S. Department of Agriculture, Forest Service, North Central Forest Experiment Station. 18 p. 
Campbell, Robert A. 1964. Forest Service log grades for southern pine. Res. Pap. SE11. Asheville, NC: U.S. Department of Agriculture, Forest Service, Southeastern Forest Experiment Station. 17 p.

Hahn, Jerold T. 1984. Tree volume and biomass equations for the Lake States. Res. Pap. NC-250. St. Paul, MN: U.S. Department of Agrculture, Forest Service. North Central Forest Experiment Station. $10 \mathrm{p}$.

Hanks, Leland F. 1976. Hardwood tree grades for factory lumber. Res. Pap. NE-333. Broomall PA: U.S. Department of Agriculture, Forest Service, Northeastern Forest Experiment Station. 81 p.

Hansen, Mark H. 1990. A comprehensive sampling system for forest inventory based on an indloidual tree growth model. St. Paul, MN: University of Minnesota, College of Natural Resources. 256 p. Ph.D. dissertation.

Little, Elbert L. 1981. Checklist of native and naturalized trees of the United States. Agric. Handb. 541. Washington, DC: U.S. Department of Agriculture, Forest Service. 385 p.

Loetsch, F.; Haller, K.E. 1964. Forest inventory. volume 1, Statistics of forest inventory and information from aerial photographs. BLV Verlagsgesellschaft Munch Basle Vienna. 436 p.

Ostrander, Myron D.: Brisbin, Robert L. 1971. Sawlog grades for eastern white pine. Res. Pap. NE-205. Upper Darby, PA: U.S. Department of Agriculture, Forest Service. Northeastern Forest Experiment Station. $24 \mathrm{p}$.

Rast, Everette D.; Sonderman, David L.; Gammon, Glenn L. 1973. A guide to hardwood log grading. Gen. Tech. Rep. NE-1. Upper Darby, PA: U.S. Department of Agriculture, Forest Service, Northeastern Forest Experiment Station. 31 p.
Smith. W.Brad. 1983. Adjusting the STEMS regional growth models to improve local predictions. Res. Note NC-297. St. Paul, MN: U.S. Department of Agriculture. Forest Service, North Central Forest Experiment Station. $5 \mathrm{p}$.

VanDeusen, P.C.: Dell, T.R.; Thomas, C.E. 1986. Volume growth estimation from permanent horizontal points. Forest Science. 32: 415-422.

Wiant, Harry V., Jr.: Castenaeda, Froylan. 1977. Mesavage and Girard's volume tables formulated. BLM4. Denver, CO: U.S. Department of the Interior, Bureau of Land Management, Denver Service Center: $1-4$.

\section{Table Titles}

Table 1.-Area by county and major land-use class, Hiawatha National Forest, Michigan, 1993

Table 2.-Area of timberland by forest type and stand stze, Hiawatha National Forest, 1993

Table 3.-Area of timberland by forest type and stand-age class, Hiawatha National Forest, 1993

Table 4.-Area of timberland by forest type and potential productivity class. Hiawatha National Forest, 1993

Table 5.-Area of timberland by forest type and stocking class of growing-stock trees, Hiawatha National Forest, 1993

Table 6.-Number of all live trees on timberland by species group and diameter class, Hiawatha National Forest, 1993

Table 7.-Net volume of all live trees and growing-stock trees on timberland by Ranger District and major species group, Hiawatha National Forest. 1993 
Table 8.-Net volume of all live trees on timberland by species group and forest type, Hiawatha National Forest, 1993

Table 9.-Net volume of growing-stock trees on timberland by species group and diameter class, Hiawatha National Forest, 1993

Table 10.-Net volume of sawtimber on timberland by species group and diameter class, Hiawatha National Forest. 1993

Table 11.-Net volume of growing stock and sawtimber on timberland by county and major species group, Hiawatha National Forest, 1993

Table 12.-Net volume of timber on timberland by class of timber and major species group. Hiawatha National Forest, 1993
Table 13.-Average net annual growth of growing stock and sawtimber on timberland by county and major species group, Hiawatha National Forest, 1980 - 1992

Table 14.-Average annual removals of growing stock and sawtimber on timberland by county and major species group, Hiawatha National Forest, 1980 - 1992

Table 15.-Average net annual growth, average annual mortality, and average annual removals of growing stock and sawtimber on timberland by species group. Hiawatha National Forest, 1980 - 1992

Table 16.-Volume of sawtimber on timberland by species group and butt log grade or tree grade, Hiawatha National Forest, 1993 
Table 1.--Area by county and major land-use class,

Hiawatha National Forest, Michigan, 1993

(In thousand acres)

\begin{tabular}{crrrrrr}
\hline & & \multicolumn{7}{c}{ Forest land } & \\
\cline { 3 - 7 } & $\begin{array}{r}\text { Total } \\
\text { land } \\
\text { County }\end{array}$ & $\begin{array}{r}\text { All } \\
\text { forest } \\
\text { land }\end{array}$ & $\begin{array}{r}\text { Timber- } \\
\text { land }\end{array}$ & $\begin{array}{r}\text { Reserved } \\
\text { timber- } \\
\text { land }\end{array}$ & $\begin{array}{r}\text { Other } \\
\text { forest } \\
\text { land }\end{array}$ & $\begin{array}{r}\text { Non- } \\
\text { forest } \\
\text { land }\end{array}$ \\
\hline Alger & 127.3 & 121.9 & 105.3 & 13.2 & 3.4 & 5.4 \\
Chippewa & 244.0 & 225.0 & 204.0 & 17.4 & 3.6 & 19.0 \\
Delta & 241.6 & 220.6 & 218.9 & - & 1.7 & 21.0 \\
Mackinac & 151.7 & 141.8 & 119.6 & 22.2 & - & 9.9 \\
Schoolcraft & 122.5 & 109.4 & 103.9 & 5.5 & - & 13.1 \\
Marquette & 5.0 & 5.0 & 5.0 & - & - & - \\
\cline { 2 - 7 } All counties & 892.1 & 823.7 & 756.7 & 58.3 & 8.7 & 68.4 \\
\hline
\end{tabular}

Note: The timberland total includes 298,700 acres identified in the Forest Plan as "reserved" land that had not been located on the ground before this survey.

Table 2.--Area of timberland by forest type and stand size,

Hiawatha National Forest, 1993

(In thousand acres)

\begin{tabular}{lrrrr}
\hline & All & \multicolumn{4}{c}{ Stand-size class } \\
\cline { 2 - 5 } stands & Sawtimber & Poletimber & $\begin{array}{c}\text { Seedling \& } \\
\text { sapling }\end{array}$ \\
\hline Jack pine & 69.9 & 22 & 45 & 2.9 \\
Red pine & 81.3 & 52.1 & 7.9 & 21.3 \\
White pine & 17.7 & 17.7 & - & - \\
Balsam fir & 35.3 & 5.2 & 7.3 & 22.8 \\
White spruce & 23.6 & 4.8 & 9.3 & 9.5 \\
Black spruce & 62.7 & 12.7 & 11.7 & 38.3 \\
Northern white-cedar & 84.3 & 22.4 & 46.8 & 15.1 \\
Tamarack & 5.2 & - & - & 5.2 \\
Oak-hickory & 16.7 & - & 2.0 & 14.7 \\
Elm-ash-soft maple & 24.8 & 2.2 & 14.3 & 8.3 \\
Maple-birch & 236.1 & 134.7 & 44.6 & 56.8 \\
Aspen & 81.3 & 22.2 & 15.2 & 43.9 \\
Paper birch & 4.8 & 4.8 & - & - \\
Balsam poplar & 13.0 & 2.6 & 4.5 & 5.9 \\
All types & 756.7 & 303.4 & 208.6 & 244.7 \\
\hline
\end{tabular}




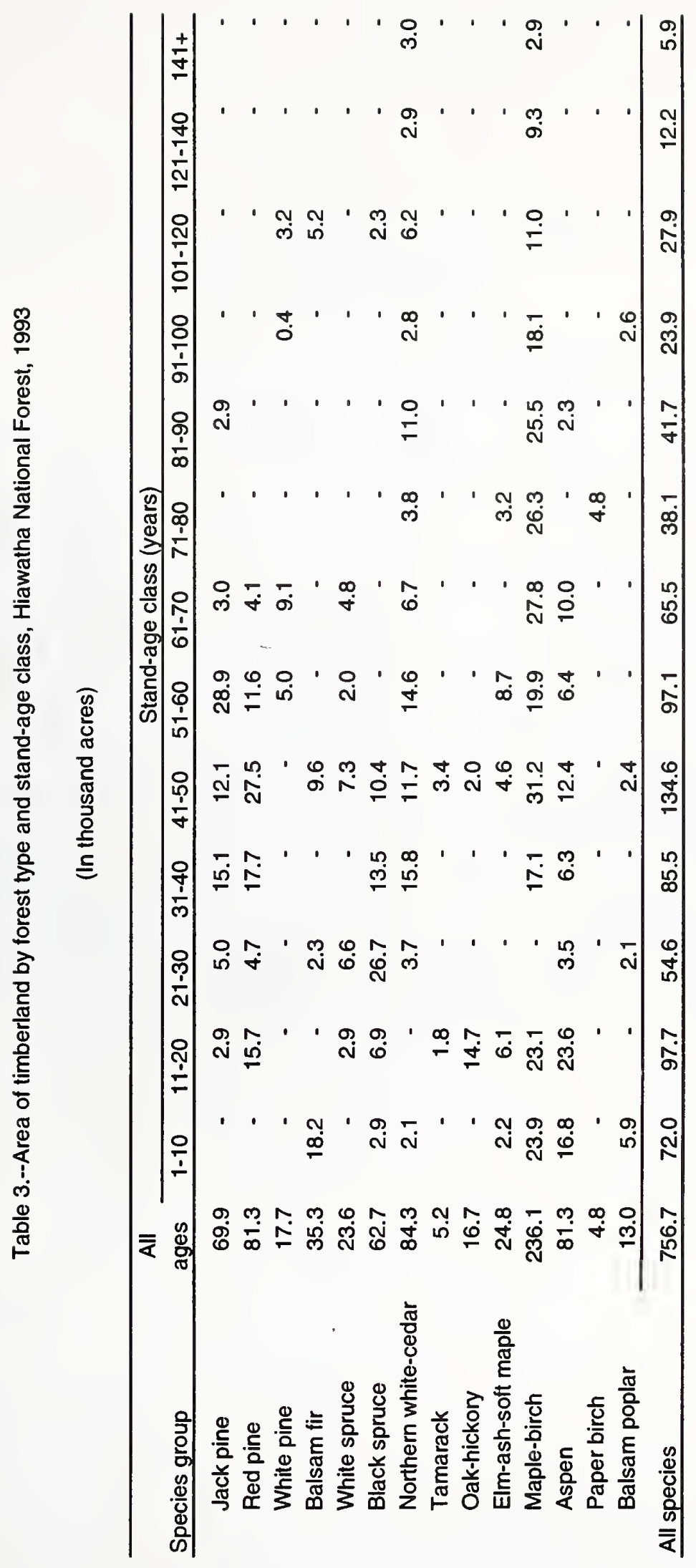


Table 4.--Area of timberland by forest type and potential productivity class, Hiawatha National Forest, 1993

(In thousand acres)

\begin{tabular}{|c|c|c|c|c|c|}
\hline Forest type & $\begin{array}{c}\text { All } \\
\text { classes }\end{array}$ & $\begin{array}{l}120+ \\
\text { cu. ft. }\end{array}$ & $\begin{array}{c}85-119 \\
\text { cu. ft. }\end{array}$ & $\begin{array}{l}50-84 \\
\mathrm{cu} . \mathrm{ft} .\end{array}$ & $\begin{array}{l}\text { Less than } \\
49 \mathrm{cu} . \mathrm{ft} \text {. }\end{array}$ \\
\hline Jack pine & 69.9 & - & - & 21.2 & 48.7 \\
\hline Red pine & 81.3 & 19.1 & 36.1 & 26.1 & - \\
\hline White pine & 17.7 & - & 6.1 & 4.9 & 6.7 \\
\hline Balsam fir & 35.3 & 5.4 & 16.5 & 2.3 & 11.1 \\
\hline White spruce & 23.6 & - & 7.7 & 15.9 & - \\
\hline Black spruce & 62.7 & - & - & 23.4 & 39.3 \\
\hline Northern white-cedar & 84.3 & - & - & 15.6 & 68.7 \\
\hline Tamarack & 5.2 & - & - & - & 5.2 \\
\hline Oak-hickory & 16.7 & - & - & 5.3 & 11.4 \\
\hline Elm-ash-soft maple & 24.8 & - & - & - & 24.8 \\
\hline Maple-birch & 236.1 & - & 37.8 & 132.7 & 65.6 \\
\hline Aspen & 81.3 & - & 17.7 & 37.6 & 26.0 \\
\hline Paper birch & 4.8 & - & - & 4.8 & - \\
\hline Balsam poplar & 13.0 & - & 4.2 & 8.8 & - \\
\hline All types & 756.7 & 24.5 & 126.1 & 298.6 & 307.5 \\
\hline
\end{tabular}


Table 5.--Area of timberland by forest type and stocking class of growing-stock trees, Hiawatha National Forest, 1993

(In thousand acres)

\begin{tabular}{|c|c|c|c|c|}
\hline \multirow[b]{2}{*}{ Forest type } & \multirow[b]{2}{*}{$\begin{array}{c}\text { All } \\
\text { classes } \\
\end{array}$} & \multicolumn{3}{|c|}{ Stocking class } \\
\hline & & $\begin{array}{l}\text { Poorly } \\
\text { stocked }\end{array}$ & $\begin{array}{c}\text { Moderately } \\
\text { stocked }\end{array}$ & $\begin{array}{c}\text { Fully } \\
\text { stocked }\end{array}$ \\
\hline Jack pine & 69.9 & 5.6 & 25.1 & 39.2 \\
\hline Red pine & 81.3 & - & 10.5 & 70.8 \\
\hline White pine & 17.7 & - & 1.3 & 16.4 \\
\hline Balsam fir & 35.3 & 13.8 & 6.8 & 14.7 \\
\hline White spruce & 23.6 & - & 6.6 & 17.0 \\
\hline Black spruce & 62.7 & - & 15.2 & 47.5 \\
\hline Northern white-cedar & 84.3 & 7.6 & 4.7 & 72.0 \\
\hline Tamarack & 5.2 & - & 5.2 & - \\
\hline Oak-hickory & 16.7 & - & - & 16.7 \\
\hline Elm-ash-soft maple & 24.8 & - & 3.8 & 21.0 \\
\hline Maple-birch & 236.1 & - & 9.4 & 226.7 \\
\hline Aspen & 81.3 & 3.5 & 12.8 & 65.0 \\
\hline Paper birch & 4.8 & - & 4.8 & - \\
\hline Balsam poplar & 13.0 & 2.1 & 2.1 & 8.8 \\
\hline All types & 756.7 & 32.6 & 108.3 & 615.8 \\
\hline
\end{tabular}




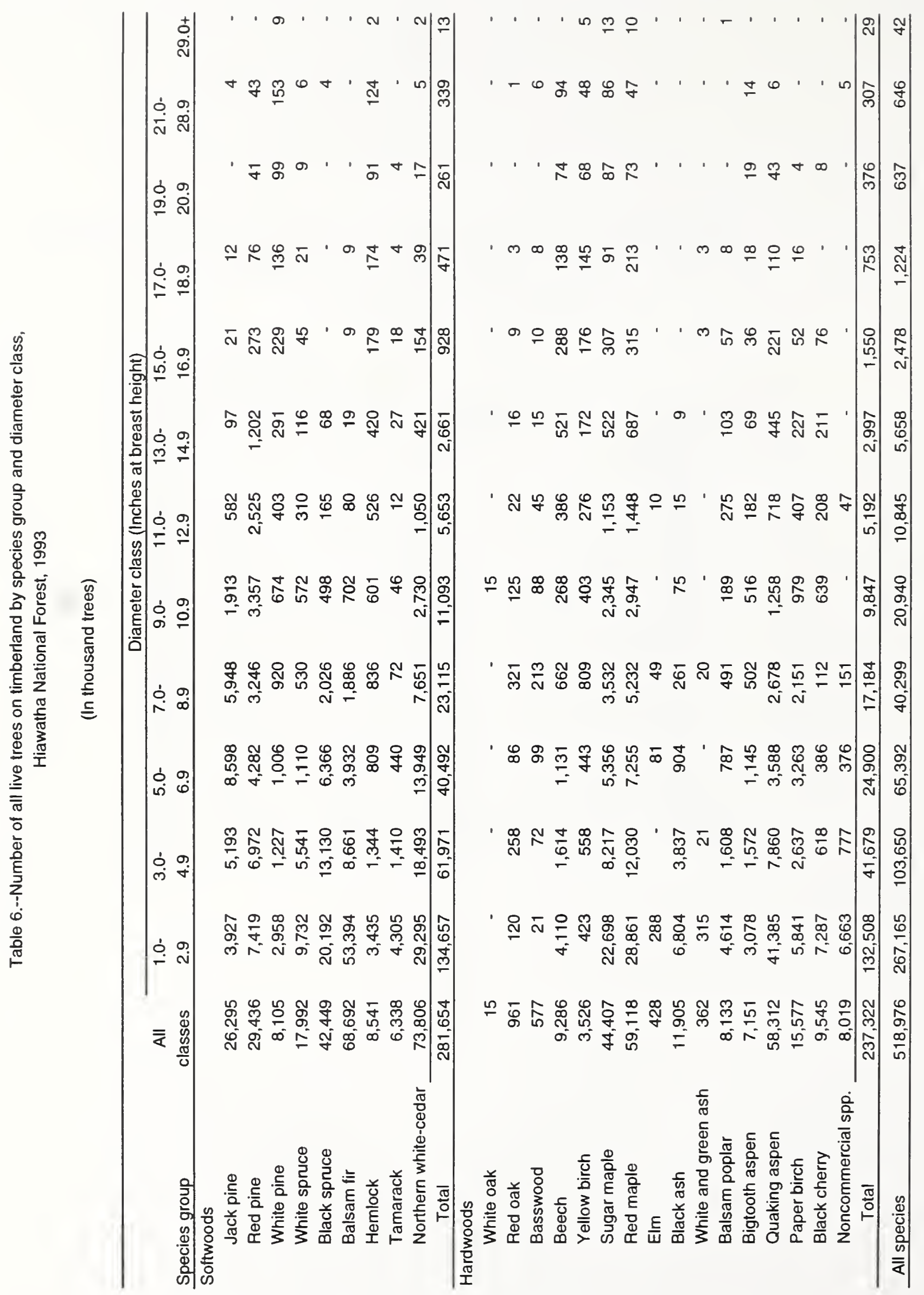




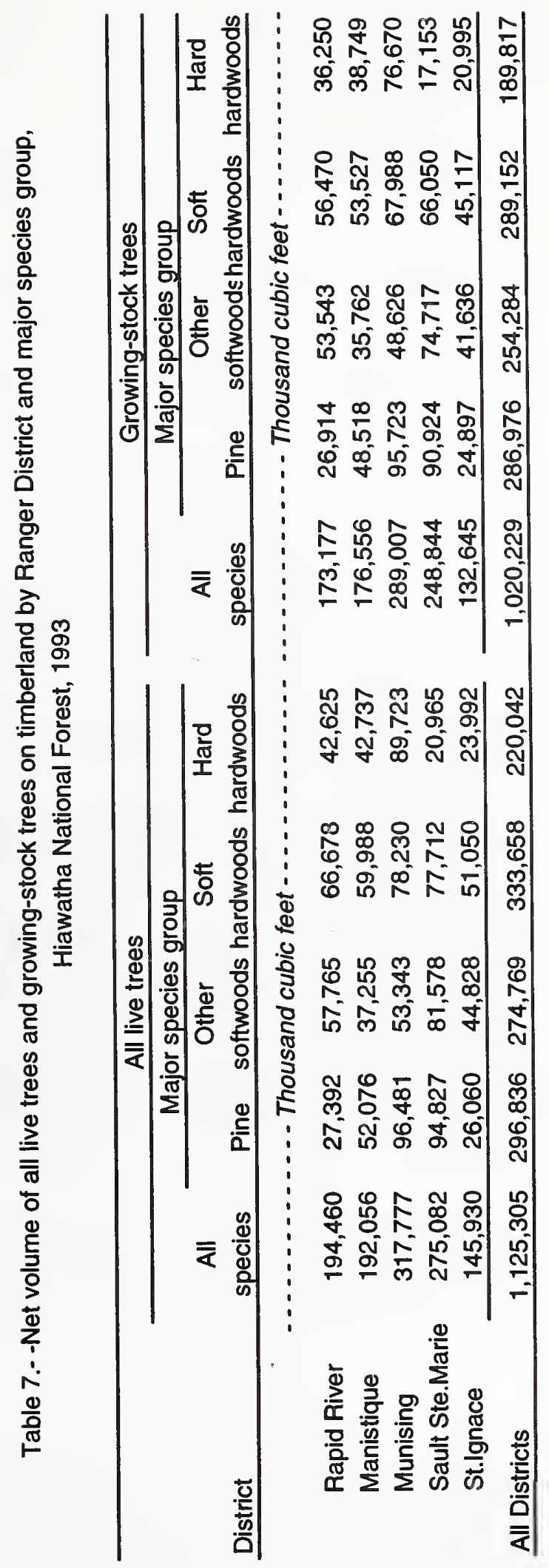




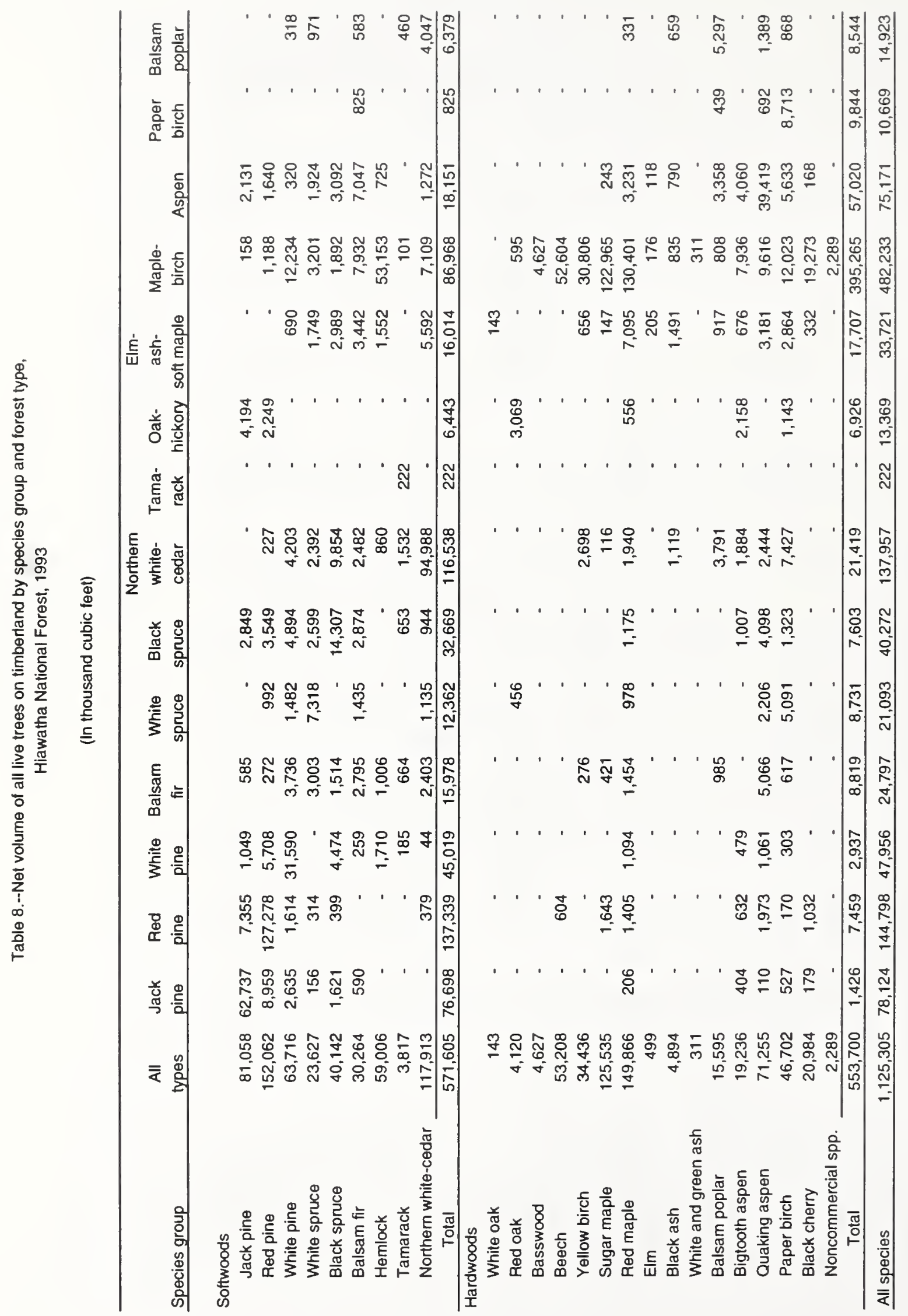




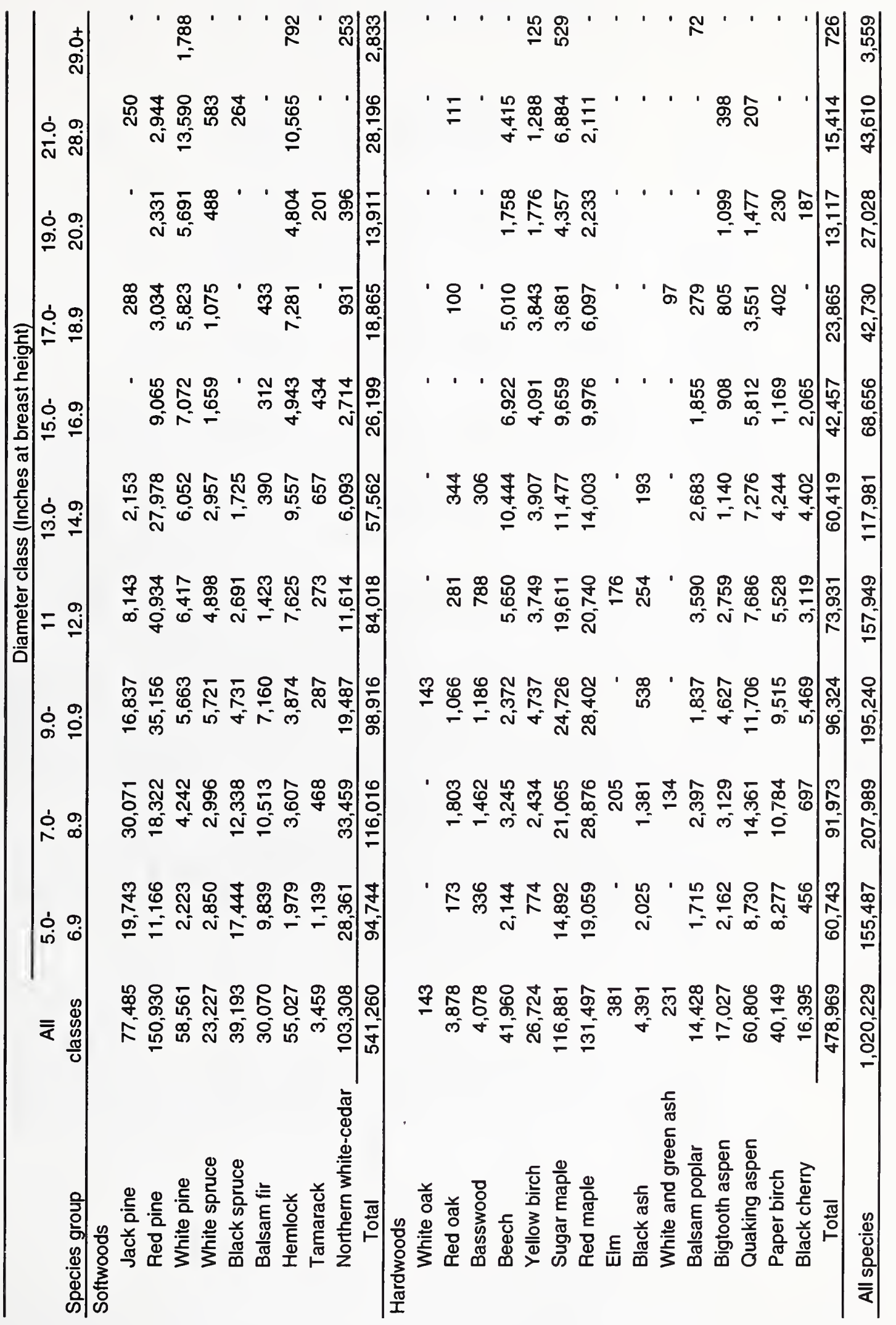




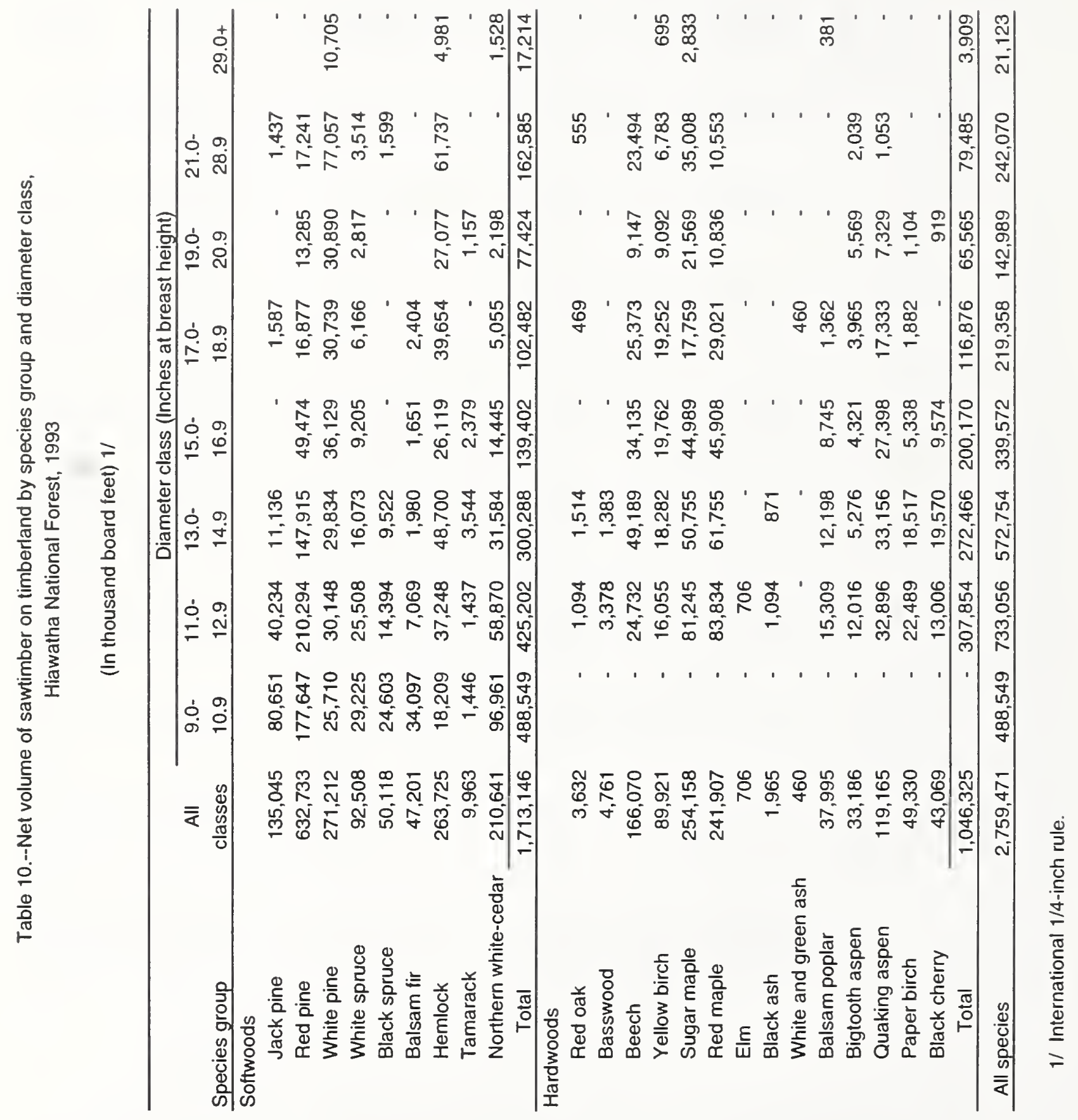




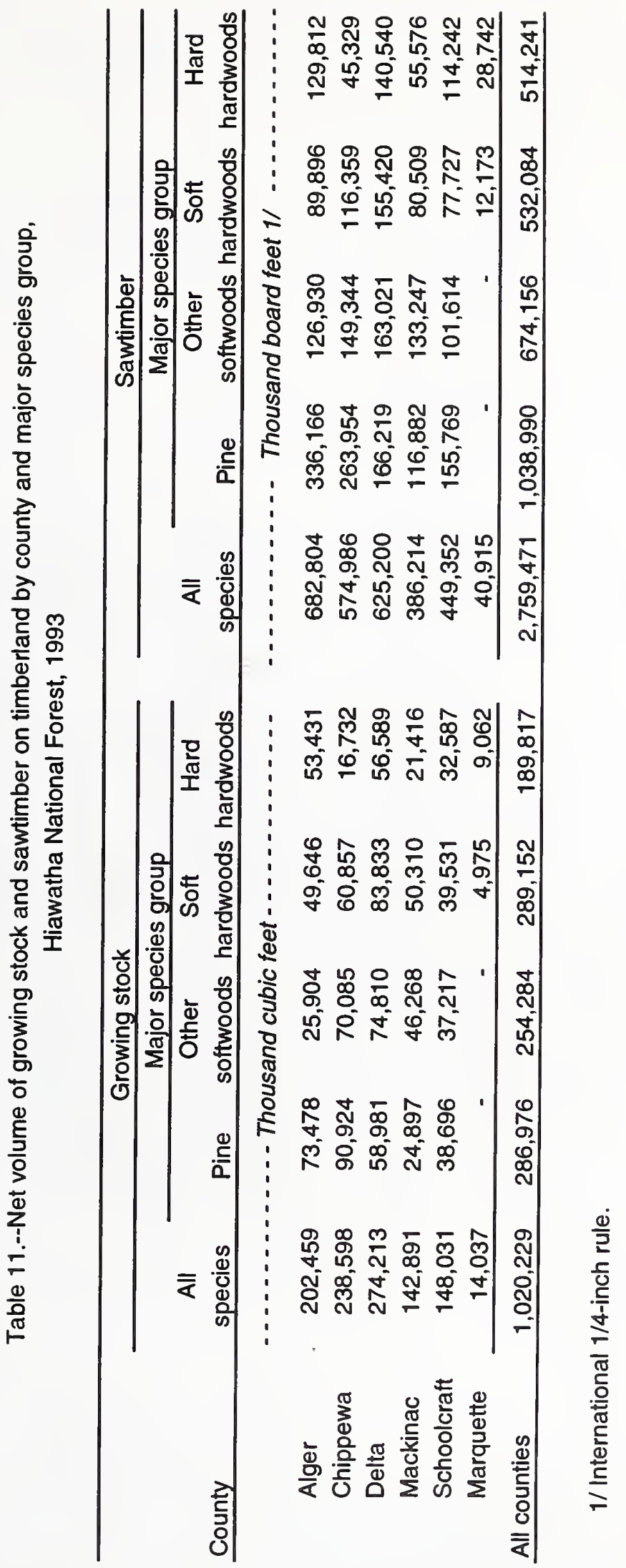








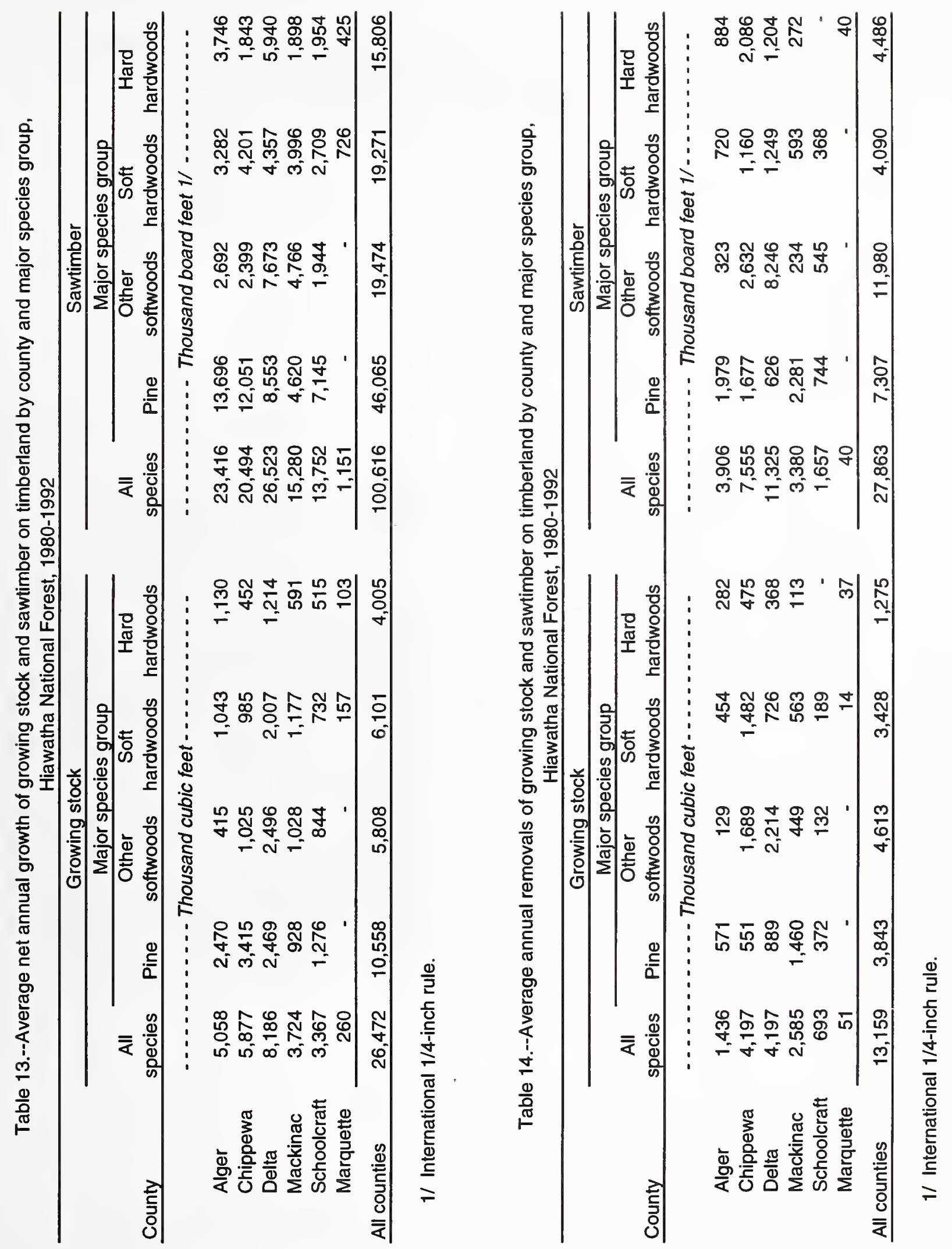
Table 15.--Average net annual growth, average annual mortality, and average annual removals of growing stock and sawtimber on timberland by species group,

Hiawatha National Forest, 1980-1992

\begin{tabular}{|c|c|c|c|c|c|c|}
\hline \multirow[b]{2}{*}{ Species group } & \multicolumn{3}{|c|}{ Growing stock } & \multicolumn{3}{|c|}{ Sawtimber } \\
\hline & $\begin{array}{c}\text { Average } \\
\text { net annual } \\
\text { growth }\end{array}$ & $\begin{array}{c}\text { Average } \\
\text { annual } \\
\text { mortality }\end{array}$ & $\begin{array}{c}\text { Average } \\
\text { annual } \\
\text { removals }\end{array}$ & $\begin{array}{c}\text { Average } \\
\text { net annual } \\
\text { growth }\end{array}$ & $\begin{array}{c}\text { Average } \\
\text { annual } \\
\text { mortality }\end{array}$ & $\begin{array}{c}\text { Average } \\
\text { annual } \\
\text { removals }\end{array}$ \\
\hline & \multicolumn{3}{|c|}{.... . Thousand cubic feet .... . - } & \multicolumn{3}{|c|}{ - . - . Thousand board feet $1 / \ldots$} \\
\hline \multicolumn{7}{|l|}{ Softwoods } \\
\hline Jack pine & 1,764 & 862 & 1,983 & 5,971 & 1,577 & 2,487 \\
\hline Red pine & 6,875 & 9 & 1,524 & 30,456 & 99 & 3,105 \\
\hline White pine & 1,919 & 92 & 336 & 9,638 & 295 & 1,715 \\
\hline White spruce & 1,808 & 387 & 2,427 & 6,058 & 1,743 & 8,967 \\
\hline Black spruce & 114 & 969 & 504 & $-1,077$ & 1,768 & 900 \\
\hline Balsam fir & 399 & 1,012 & 845 & 2,036 & 2,338 & 833 \\
\hline Hemlock & 863 & 186 & 154 & 5,505 & 796 & 804 \\
\hline Tamarack & 79 & 34 & 36 & 137 & 90 & - \\
\hline Northem white-cedar & 2,545 & 317 & 647 & 6,815 & 930 & 476 \\
\hline Total & 16,366 & 3,868 & 8,456 & 65,539 & 9,636 & 19,287 \\
\hline \multicolumn{7}{|l|}{ Hardwoods } \\
\hline White oak & 4 & $\cdot$ & - & 134 & - & - \\
\hline Red oak & 79 & 9 & - & 315 & 11 & 257 \\
\hline Basswood & 96 & 36 & 88 & 5,377 & 6 & 630 \\
\hline Beech & 970 & 72 & 245 & 1,017 & 212 & 2,042 \\
\hline Yellow birch & -31 & 271 & 454 & 9,276 & 1,059 & 1,814 \\
\hline Sugar maple & 2,983 & 333 & 576 & 9,118 & 839 & 1,674 \\
\hline Red maple & 3,300 & 464 & 1,062 & -26 & 468 & - \\
\hline Elm & -35 & 62 & - & 122 & 151 & - \\
\hline Black ash & 140 & 37 & - & 2 & - & - \\
\hline Balsam poplar & 170 & 547 & 116 & 117 & 1,644 & - \\
\hline Bigtooth aspen & 418 & 198 & 272 & 1,275 & 276 & 497 \\
\hline Quaking aspen & 1,419 & 1,332 & 938 & 6,769 & 2,333 & 448 \\
\hline Paper birch & 317 & 591 & 614 & 412 & 858 & 1,016 \\
\hline Black cherry & 276 & 67 & 338 & 1,169 & 155 & 198 \\
\hline Total & 10,106 & 4,019 & 4,703 & 35,077 & 8,012 & 8,576 \\
\hline All species & 26,472 & 7,887 & 13,159 & 100,616 & 17,648 & 27,863 \\
\hline
\end{tabular}

1/ International 1/4-inch rule. 
Table 16.--Volume of sawtimber on timberland by species group and butt log grade or tree grade, Hiawatha National Forest, 1993

(In thousand board feet) $1 /$

\begin{tabular}{|c|c|c|c|c|c|}
\hline \multirow[b]{2}{*}{ Species } & \multicolumn{5}{|c|}{ Butt log grade } \\
\hline & $\begin{array}{c}\text { All } \\
\text { grades }\end{array}$ & 1 & 2 & 3 & 4 \\
\hline \multicolumn{6}{|l|}{ Softwoods } \\
\hline Jack pine & 135,045 & - & - & 135,045 & - \\
\hline Red pine & 632,733 & 4,071 & 18,190 & 610,472 & - \\
\hline White pine & 271,212 & 56,099 & 53,026 & 97,229 & 64,858 \\
\hline White spruce & 92,508 & - & 1,733 & 90,775 & - \\
\hline Black spruce & 50,118 & - & - & 50,118 & - \\
\hline Balsam fir & 47,201 & - & - & 47,201 & - \\
\hline Hemlock & 263,725 & 20,308 & 36,061 & 207,356 & - \\
\hline Tamarack & 9,963 & - & - & 9,963 & - \\
\hline Northern white-cedar & 210,641 & - & - & 210,641 & - \\
\hline \multirow[t]{3}{*}{ Total } & $1,713,146$ & 80,478 & 109,011 & $1,458,799$ & 64,858 \\
\hline & \multicolumn{5}{|c|}{ Tree grade } \\
\hline & $\begin{array}{c}\text { All } \\
\text { grades }\end{array}$ & 1 & 2 & 3 & $\begin{array}{c}\text { Tie } \\
\text { and timber }\end{array}$ \\
\hline \multicolumn{6}{|l|}{ Hardwoods } \\
\hline Red oak & 3,632 & - & 1,664 & - & 1,968 \\
\hline Basswood & 4,761 & - & 2,321 & 2,440 & - \\
\hline Beech & 166,070 & 18,945 & 66,984 & 51,377 & 28,765 \\
\hline Yellow birch & 89,921 & 10,485 & 38,744 & 34,731 & 5,961 \\
\hline Sugar maple & 254,158 & 19,811 & 86,973 & 124,606 & 22,768 \\
\hline Red maple & 241,907 & 18,254 & 69,880 & 123,852 & 29,920 \\
\hline Elm & 706 & - & - & 706 & - \\
\hline Black ash & 1,965 & - & - & 1,965 & - \\
\hline White and green ash & 460 & - & - & 460 & - \\
\hline Balsam poplar & 37,995 & 2,214 & 9,959 & 12,355 & 13,467 \\
\hline Bigtooth aspen & 33,186 & 5,807 & 4,683 & 18,891 & 3,805 \\
\hline Quaking aspen & 119,165 & 11,655 & 44,623 & 45,223 & 17,664 \\
\hline Paper birch & 49,330 & - & 11,537 & 33,044 & 4,749 \\
\hline Black cherry & 43,069 & - & 25,079 & 17,114 & 875 \\
\hline Total & $1,046,325$ & 87,172 & 362,446 & 466,765 & 129,942 \\
\hline All species & $2,759,471$ & 167,650 & 471,457 & $1,925,564$ & 194,800 \\
\hline
\end{tabular}

1/ International 1/4-inch rule. 
The Unied States Deparment of Agriculuure (USDA) prohbits discrimination in the programs on the basis of race, color, national origin, sex, religion, age, disablithy. political beliels and martal or familial status. (Not all prohbited bases apply to all programs.) Persons with dis abilikes who require ahemative means for communication of program information (brallie, large print, audiotape, etc) shouid contact the USDA Otlice of Communication at (202) 720-5881 (volico) or (202) 720-7808 (TDD).

To lile a complaint, write the Sectetary of Agriculure, U.S. Depanment of Agriculture, Washington, D.C. 20250 , or call (202) $720-7327$ (volce) or (202) 7201127 (TDO). USDA is an equal employment oppontunity employer. 


Schmidt, Thomas; Lanasa, Mike.

1995. The forest resources of the Hiawatha National Forest, 1993. Resour. Bull. NC-163. St. Paul, MN: U.S. Department of Agriculture, Forest Service, North Central Forest Experiment Station. $35 \mathrm{p}$.

The inventory of the forest resources of the Hiawatha National Forest reports 892.1 thousand acres of land, of which 756.7 thousand acres are forested. This bulletin presents statistical highlights and contains detailed tables of forest area, as well as of timber volume, growth, removals, and mortality.

KEY WORDS: Forest area, timber volume, growth, removals, mortality. 
Our job at the North Central Forest Experiment Station is discovering and creating new knowledge and technology in the field of natural resources and conveying this information to the people who can use it. As a new generation of forests emerges in our region, managers are confronted with two unique challenges: (1) Dealing with the great diversity in composition, quality, and ownership of the forests, and (2) Reconciling the conflicting demands of the people who use them. Helping the forest manager meet these challenges while protecting the environment is what research at North Central is all about. 